\section{A JUSTIFICAÇÃO DOS DIREITOS FUNDAMENTAIS}

Recebimento do artigo: 15/04/2007

Aprovado em: 17/05/2007

\section{Antonio Carlos Campos Pedroso}

\section{Sumário}

Introdução. O problema da justificação dos direitos fundamentais. 1 As dimensões da pessoa humana como ponto de partida para a compreensão dos direitos fundamentais. 2 A dignidade da pessoa humana como princípio reclamado pelo seu estatuto ontológico. 3 Evolução histórico-filosófica do princípio da dignidade da pessoa humana desde a filosofia clássica até à filosofia moderna. Sua efetiva configuração no pensamento de Kant. 4 As exigências éticas que decorrem da imagem valorativa do ser humano. O princípio ético de mútuo respeito como imperativo axiológico nas relações de intersubjetividade. 5 A configuração dos direitos e deveres humanos realizada pelo processo de positivação, como trânsito dos direitos humanos, eticamente definidos, aos direitos fundamentais, juridicamente tipificados. Enunciados finais.

\section{Resumo}

O presente estudo suscita, de início, uma reflexão sobre os fundamentos, de ordem antropológica e ética, dos direitos humanos. Em seguida, procura demonstrar que os referidos direitos constituem mandamentos éticos, por serem decorrentes da dignidade da pessoa humana. Finalmente, sustenta que tais mandamentos, quando assumidos pela Constituição, adquirem, por acréscimo, o caráter de princípios jurídicos que inspiram todo o conjunto normativo.

\section{Palavras-chave}

Dignidade humana. Mandamentos éticos. Princípio do mútuo respeito. Valores jurídicos. Direitos e deveres fundamentais 


\title{
O problema
}

É inegável que as Declarações dos Direitos Humanos revelam valores jurídicos. Há em seus princípios evidente substrato axiológico, um tesouro a ser preservado. Assim sendo, torna-se necessário saber de que fonte material referidos ordenamentos procedem. Não podemos conceber a admissão de direitos humanos sem a sua imprescindível justificação. As Declarações de Direitos Humanos constituem sistemas jurídicos ulteriores a determinados dados prévios que consubstanciam valorações éticas da convivência humana.

Intentamos, no presente trabalho, relembrar, os supostos filosóficos em que se assentam os direitos fundamentais. Estes, no nosso entender, constituem direitos naturais ou humanos que, por acréscimo, receberam, pela positivação, a categoria da juridicidade. É preciso ir às raízes dos referidos direitos, procurando entrever a sua explicação última e os passos do movimento que deu margem à sua configuração histórica. Trata-se de perspectiva adotada por pensadores que não se contentam com a mera análise dogmática dos direitos fundamentais.

Semelhante entendimento vem preconizado, entre outros pensadores, por Gregório Robles. Segundo seu modo de pensar, há dois problemas que não se confundem: em primeiro lugar, o problema prático, que é o da realização dos direitos fundamentais; em segundo lugar, o problema teórico, que é o de sua fundamentação. Este último não pode ser tido e havido como pseudoproblema. Razões de ordem ética, lógica, teórica e pragmática exigem adequada consideração. Assim se expressa Gregório Robles:

\begin{abstract}
O fundamento dos direitos humanos constitui realmente um problema e, além do mais, um problema que não podemos ocultar. Isso ocorre por várias razões. A primeira é o absurdo de defender algum valor sem saber por quê. A segunda é o fato de o referido porquê ou fundamento delimitar o conteúdo concreto, em uma ou outra direção, dos direitos humanos. A terceira é ser francamente ridículo e inaceitável que nós, teóricos, apresentemos teorias sobre os direitos, sem fundamentá-las. Por último, a quarta, para conduzir a prática de tais direitos, é necessário, pelo menos, ter idéias claras. Diremos que a primeira razão é ética, a segunda é lógica, a terceira é teórica e a quarta, pragmática ${ }^{1}$.
\end{abstract}

Idêntico é o pensamento de Francisco Carpintero. Sustenta o professor da Universidade de Cadiz que o fato de os direitos fundamentais constituírem produto de longo evolver histórico não elimina a necessidade de se perquirir a respeito de sua base ontológica, preexistente à sua configuração e efetividade. Esclarecimentos

\footnotetext{
${ }^{1}$ ROBLES, Gregório. Os direitos fundamentais e a ética na sociedade atual. Tradução de Roberto Barbosa Alves. São Paulo: Manole, 2005, p. 1.
} 
atinentes à evolução histórica são absolutamente necessários porque suscitam a análise das valorações que referidos direitos traduzem. É o que se deduz de suas lições. Os direitos humanos não podem ser simplesmente considerados produtos da história, na dependência exclusiva de fatores circunstanciais de determinado momento histórico. A historicidade não constitui óbice à existência de princípios permanentes ${ }^{2}$. Há uma Antropologia e uma Ética subjacentes ao direitos humanos. É, pois, preciso compreender os dados prévios à positivação dos mencionados direitos.

Atendendo a estas ponderações, pretendemos, numa sucinta e breve reflexão sobre a gênese dos direitos fundamentais, relembrar os dados prévios que constituem o alicerce de sua configuração. Vamos examinar os pressupostos filosóficos dos direitos fundamentais, de acordo com o seguinte esquema: 1 - as dimensões da natureza humana, como ponto de partida para a compreensão dos direitos fundamentais; 2 - a dignidade da pessoa humana, como princípio reclamado pelo estatuto ontológico da pessoa; 3 - a evolução histórico-filosófica do princípio da dignidade da pessoa humana, até o momento marcante de sua efetiva conformação; 4 - as exigências éticas que decorrem da imagem valorativa do ser humano; 5 - a configuração dos direitos e deveres humanos realizada graças ao processo de positivação, como passagem dos direitos humanos, eticamente definidos, aos direitos fundamentais, juridicamente tipificados. Parece ser este o caminho para a compreensão da gênese desses mesmos direitos. Da dignidade da pessoa humana, devidamente conceituada, decorrem determinados mandamentos éticos que, por sua vez, dão origem aos direitos humanos fundamentais. Estes não perdem a substância ética, mas adquirem, por acréscimo, a nota da juridicidade, quando normativamente acolhidos. Nestas condições, os direitos naturais passam a ser direitos imanentes ao sistema jurídico, constituindo o direito natural codificado. Assim ocorrendo, condicionam, por seus princípios, adaptados às circunstâncias

\footnotetext{
2 Assim se expressa Francesco Carpintero: "Segundo esta forma de pensar, ou melhor, de sentir, os "direitos humanos" surgiram e foram impostos em um momento histórico concreto, e são, portanto, produto da história; algo assim como o mito de Vênus, a deusa de carne e osso que nasceu da espuma do mar. Em conseqüência, a explicação de porquê existem esses direitos, como se fundamentam, não deve ser abordada. Em lugar de se proceder a esta fundamentação, a Declaração Universal de 1948, indica Ollero, se limita a declarar que os mesmos são suficientemente compartilhados em nosso momento histórico, com o que converte o problema desse fundamento, de teoricamente insolúvel a praticamente supérfluo. Com efeito, as declarações de direitos não derivam esses "direitos" da "natureza" do homem, nem os considera evidentes, mas apenas reconhece que existe acordo em mantê-los; bastaria, portanto, a intersubjetividade do consenso e, assim, chegariamos a um acordo de fato. Fundamentados sobre este acordo, filósofos e juristas, em lugar de perder tempo com abstrações teóricas acerca de sua fundamentação, deveriam dedicar-se a fazer possível a sua realização prática" (Tradução nossa. Cf. CARPINTERO, Francesco. Una introducción a la ciencia jurídica. Madrid: Civitas, 1988, p. 187).
} 
38 históricas, a realização do referido sistema, na sua integralidade. É o que preleciona Joseph Höffner.

\section{As dimensões da pessoa humana como ponto de partida para a compreensão dos direitos fundamentais}

As tendências e inclinações fundamentais da natureza humana assinalam ao ser humano uma direção, constituindo um processo dinâmico apto a conduzi-lo à realização de seus "fins existenciais". A auto-realização pessoal é fruto da realização de tendências psico-biológicas, psícossociais e psico-espirituais. Seu dinamismo se desenvolve, segundo Joseph Nuttin, em três níveis. No nível psicobiológico, encontram-se o impulso de autoconservação e o impulso sexual; no nível psicossocial, temos o impulso de sociabilidade e o de auto-afirmação; no nível psico-espiritual, podem ser mencionados o impulso de cogitação do sentido da vida e o de autotranscendência. Estes níveis constituem as tendências e inclinações da natureza humana que impulsionam o ser humano à sua realização existencial ${ }^{4}$. Esse projeto humano não é acabado, mas dependente de contínuo processo de mudança, a ser assumido no contexto históricocultural. As potencialidades devem ser atualizadas, o que se verifica quando o ser humano procura transcender-se a si mesmo ${ }^{5}$.

Além das notas que caracterizam o ser humano no mundo da natureza, é de suma importância relembrar sua inserção no mundo da cultura. Trata-se de contribuição decisiva da antropologia moderna. O homem tem uma natureza e tem uma cultura. Em conseqüência, a historicidade é a característica específica que o define. Como bem assinala Ramón Lucas Lucas, "a idéia fundamental que se deseja exprimir com o conceito de historicidade é que o homem é constitutivamente um ser de cultura e que a criação de um mundo mais humano, em colaboração com todas as gerações, é uma tarefa da existência histórica". E acrescenta: "mais do

\footnotetext{
${ }^{3}$ HOFFNER, Joseph. Doctrina social cristiana. Tradução de Lucio Garcia Ortega. Madrid: Ediciones Rialp, 1964, p. 64-67.

${ }^{4}$ NUTTIN, Joseph. Psicanálise e personalidade. Tradução de Geraldo Servo. São Paulo: Agir, p. 313 e segs.

${ }^{5}$ A autotranscendência em determinadas direções é explicada por Gordon W. Allport nestes termos; "Esse aspecto do pensamento existencialista (refere-se o psicólogo ao desenvolvimento da personalidade) vai além do objetivo de atualizar-se a si mesmo. Efetivamente, coloca para o homem o problema de que potencialidades, dentre as muitas que possui, escolherá para atualizá-las. É necessário transcender-se a si mesmo, examinar as próprias capacidades e os próprios desejos como se viessem de fora, incluídos em um contexto objetivo e até cósmico. Sob esse ponto de vista, a capacidade de transcender-se a si mesmo e de assumir responsabilidades é o verdadeiro núcleo significativo da pessoa humana" (Tradução nossa). Cf. ALLPORT, Gordon W. La personalidad, su configuración y desarollo, tradução de Ismael Antichi, Barcelona, Herder Editora, 1973, p. 650).
} 
que insistir que o homem tem uma natureza, se deve insistir no fato de que o homem tem uma cultura, um projeto, uma missão a realizar, significando com isto o conjunto da obra humanizadora do homem no tempo".

A análise fenomenológica da pessoa humana revela as notas que a caracterizam. Não cabe, no âmbito deste estudo, uma pesquisa aprofundada do constitutivo da pessoa, segundo a Antropologia Filosófica. Mas, impõe-se, para fixar melhor o conceito de dignidade da pessoa humana, uma explicação sumária de suas dimensões. Estas evidenciam que o ser humano tem fins próprios. Tem um projeto existencial a ser cumprido e este revela os componentes de sua dignidade.

São as seguintes as dimensões a serem analisadas: racionalidade, liberdade, sociabilidade, historicidade e espiritualidade. Estas dimensões constituem as estruturas fundamentais do ser humano, que possibilitam seu relacionamento com o mundo, com os outros e com o Absoluto. No dizer de Henrique Cláudio de Lima Vaz, constituem as relações de objetividade (com o mundo), intersubjetividade (com os outros), e transcendência (com Deus). Vejamos, de per si, cada uma delas.

Racionalidade. Trata-se da dimensão cognoscitiva. O homem é dotado de aptidões para chegar ao conhecimento sensível e intelectual, sendo, ainda, possuidor de faculdades que lhe permitem contar com o conhecimento intuitivo. A capacidade cognoscitiva pode ser apreciada sob tríplice aspecto: capacidade de abstração e elaboração de conceitos universais; capacidade para formar juízos, isto é, para afirmar ou negar um pensamento de outro; e capacidade para inferir um juízo de outro, formulando, assim, um raciocínio. Por isso, a idéia, o juízo e o raciocínio constituem, na verdade, as operações do espírito para o pensamento correto ${ }^{7}$. Pode o ser humano, ampliando o horizonte de suas especulações, alcançar o conhecimento científico, já que possui estrutura de pensamento apta à pesquisa e formulação de tipos, leis e princípios. Ciência é o conhecimento das coisas pelas suas causas. O ser humano é capaz de realizá-lo. Em conclusão, o homem é um ser racional. É o bomo sapiens.

É a razão que coloca o ser humano numa situação privilegiada com relação aos demais elementos da natureza, conferindo-lhe especial posição no conjunto harmônico dos seres. A possibilidade do conhecimento intelectual é um dos

\footnotetext{
${ }^{6}$ Tradução nossa. Cf. LUCAS LUCAS, Ramón. L’Uomo spirito incarnato. Compendio di filosofia dell’Uomo, Torino: Edizioni San Paolo, 1993, p. 224.

${ }^{7}$ JOLIVET, Regis. Traité de philosophie. Introduction générale. Logique et cosmologie. Paris: Emmanuel Vitte Éditeur, 1949, t. I, p. 58; MARITAIN, Jacques. Elementos de filosofia. A ordem dos conceitos. Lógica menor. Tradução de Ilza das Neves. Revisão de Adriano Cury. São Paulo: Agir, 1980, t. II, p. 17-21.
} 
elementos capazes de revelar o ser espiritual do homem. Como diz Emerich Coreth, é o conhecimento que revela o ser espiritual do homem. Esclarece o professor da Universidade de Innsbruck que a auto-realização depende do conhecimento. Este se encontra

$$
\begin{aligned}
& \text { sempre imerso no contexto de toda a vida humana. É um elemento } \\
& \text { integrante da conduta geral humana. Ao mesmo tempo, é um elemento } \\
& \text { primeiro e básico já que precede a todas as outras formas de auto-realização } \\
& \text { humana, tornando-as possíveis e dando-lhes uma direção }{ }^{8} \text {. }
\end{aligned}
$$

Nestas condições, lícito é concluir que esse elemento constitui base inicial para a caracterização do princípio da dignidade humana. Além disso, podemos acrescentar aos referidos conhecimentos, de caráter sensível e espiritual, o conhecimento intuitivo. Há verdades universais que podem ser apreendidas por simples contemplação, sem necessidade do discurso. Além da intuição sensível (gênese do conhecimento sensível acima referido), há a intuição intelectual que permite o conhecimento dos primeiros princípios do ser e do valor, possibilitando afirmações de ordem ontológica e axiológica. A intuição intelectual, que permite captar valores, é também base suficiente para uma demonstração da dignidade da pessoa humana. É por intuição que conseguimos captar os primeiros princípios da lei natural, os princípios básicos da atividade moral, como bem assevera Jacques Maritain?.

Liberdade. O ser humano é dotado de liberdade. Esta é a capacidade de auto determinação, a capacidade de querer e de atuar em determinada direção. Esta aptidão é o que caracteriza o homo volens. Como explica Emerich Coreth, o homem não é apenas um ser que conhece, mas um espírito capaz de eleger e decidir relativamente à auto-realização e autodesenvolvimento. Ao conhecimento seguese o querer e a ação. Ambas as características, o conhecimento e a ação, constituem componentes da realidade humana. Diz o citado professor da Universidade de Innsbruck que o conhecimento entremostra a possibilidade de decidir e de desenvolver nosso próprio ser rumo à realização existencial. A esfera de autorealização depende da atuação livre. Assim se expressa Emerich Coreth:

$$
\begin{aligned}
& \text { o conhecimento nos mostra as possibilidades de decisão e de } \\
& \text { desenvolvimento pessoal de acordo com nosso próprio ser ou de } \\
& \text { renegação desta empresa. O conhecimento nos oferece orientação relativa }
\end{aligned}
$$

\footnotetext{
${ }^{8}$ CORETH, Emerich. ¿Qué es el hombre? Esquema de una antropologia filosófica. Tradução de Andrés Ortiz-Osés, Barcelona: Herder, 1976.

${ }^{9}$ MARITAIN, Jacques. O homem e o estado. Tradução de Alceu Amoroso Lima. 4. ed. São Paulo: Agir, 1966, p. 91 e segs; MARITAIN, Jacques. Natural law and moral law. In: Challenges and Renewals. Selected readings edited by Joseph W. Evans and Leo R. Ward. Reprinted by arrangement with the University of Notre Dame. New York: The World Publishing Company, 1966, p. 213-216.
} 
ao nosso mundo e ao conjunto dos seres. Assinala-nos valores e desvalores, possibilidades autênticas e inautênticas, verdadeiras e falsas do nosso ser pessoal. Mas somos nós que temos de escolher e decidir. Em nossa auto-realização somos livres ${ }^{10}$.

Como funções correlativas e complementares do ser humano (as expressões são do mencionado professor), ambas compõem o estatuto ontológico da pessoa. A liberdade, do mesmo modo que a racionalidade, constitui elemento componente do ser humano. Ambas constituem atividades psíquicas capazes de justificar o princípio da dignidade da pessoa humana. O ser humano é o bomo sapiens e o bomo volens, sendo, por isso, portador de dignidade.

Sociabilidade. Para o seu pleno desenvolvimento, na forma acima assinalada, o ser humano depende da convivência com os demais. O personalismo da filosofia moderna já declarou, com sobejas razões, que o homem é um "ser-com-os-outros". A sociabilidade é, nesta ordem de considerações, um componente da estrutura fundamental do ser humano. A expansão em direção de outrem é fenômeno inato. O homem só pode atingir os fins existenciais no contexto social. Por sua própria conta, é incapaz de se realizar plenamente. Viver é conviver. Aliás, na Ética a Nicômaco, Aristóteles já havia indicado a sociabilidade como nota característica do homem, consignando ser o mesmo "um animal político" (Política, L. I, 1253). Joseph H. Fichter se refere à atuação do ser humano como pessoa social. Seu modo de atuar na convivência social, como socius entremostra seu envolvimento em papéis sociais. O ser humano tem personalidade social. É o ensinamento do professor americano, da Loyola University: "o indivíduo torna-se pessoa social ao nascer, porém sua personalidade social desenvolve-se através do processo de socialização" 11 .

A filosofia moderna, de cunho existencial e personalista, apregoa, como constitutivo essencial do homem, a intersubjetividade, acrescentando que esta se manifesta não só nas relações eu-tu, como também nas relações eu-nós. Assim sendo, ressalta, em ambas as hipóteses, o aspecto social e comunitário da coexistência social. A intersubjetividade é considerada elemento básico para a compreensão da

\footnotetext{
${ }^{10}$ CORETH, Emerich.¿Qué es el hombre? Esquema de una antropologia filosófica. Tradução de Andrés Ortiz-Osés. Barcelona, 1976, p. 136-140. Esclarece, ainda, o citado mestre, que "a dimensão intersubjetiva do homem deriva de dados que se impõem por si mesmos: pela sua constituição físicocorporal, o homem depende durante muito tempo de seus genitores e, tornando-se adulto, tem necessidade dos outros para a obtenção dos meios de subsistência; pela sua dimensão espiritual, o aparecimento e o desenvolvimento das faculdades espirituais dependem inteiramente da união com os outros homens. A linguagem conceitual é instrumento de intercâmbio cultural e eleva o homem acima dos outros animais. Em conseqüência, o homem somente consegue o pleno desenvolvimento humano. ${ }^{11}$ FICHTER, Joseph. H. Sociologia. Tradução de Hebe Guimarães Leme. 8. ed. São Paulo: Editora Pedagógica e Universitária , 1967, p. 37-45.
} 
pessoa humana. Segundo Ramón Lucas Lucas, o fundamento de toda relação social se encontra na abertura para o outro. Ensina o professor da Universidade Gregoriana que

\begin{abstract}
na abertura para o outro se vê a aplicação da fórmula orteguiana "eu e a minha circunstância". Sem esta abertura para a vida social, o ser humano permanece isolado; o homem torna-se visível apenas na sociabilidade, sendo altruísta. O sentido do termo homem inclui um existir de um para o outro; portanto, uma comunidade de homens, uma sociedade. Nesta abertura se encontra o fundamento mais profundo da dimensão social $^{12}$.
\end{abstract}

De acordo com a antropologia personalista, o ser humano só se realiza em comunhão com o outro; o ser da pessoa está relacionado com o ser dos outros de forma estrutural. É um ser em relação. O outro emerge em nossa existência, de modo que o ser humano só pode ser compreendido como ser-com-os-outros.

A característica acima aludida da intersubjetividade revela o elemento constitutivo da pessoa, possibilitando a comunhão, a solidariedade e a cooperação e ensejando a auto-realização. O "ser-com-os-outros" da antropologia relacional abrange a relação atinente à vida pessoal e a relação que se refere à vida social. Assim se expressa Emerich Coreth:

não só vivemos em relação com outros indivíduos humanos, como também com o conjunto da comunidade; não só estamos na relação do eu-tu, como também na relação eu-nós; em outras palavras vivemos em uma relação pessoal e também social. A relação eu-nós supõe a relação tu; é o tu que proporciona a relação eu-nós. Por outro lado, também é certo o processo inverso, criando-se as relações pessoais eu-tu através da comunidade de eu-nós, enquanto o eu-nós possibilita o tu. Existe um condicionamento e uma mediação mútuos. Ambos os aspectos formam uma unidade necessária ${ }^{13}$.

Historicidade. Como demonstramos no item anterior, o homem é um ser social. Mas, além de social, é um ser histórico. A historicidade é nota essencial para a

\footnotetext{
12 Tradução nossa. Cf. LUCAS LUCAS, Ramón. L’Uomo spirito incarnato. Compendio di filosofia dell’Uomo. Torino: Edizioni San Paolo, 1993, p. 230, 235. São seus os esclarecimentos que se seguem. “A dimensão intersubjetiva do homem deriva de dados que se impõem por si mesmos: pela sua constituição físico-corpórea, o homem depende por longo tempo de seus genitores e, tornando-se adulto, tem necessidade dos outros para a aquisição dos meios de sobrevivência; pela sua dimensão espiritual, o aparecimento e o desenvolvimento das faculdades espirituais dependem inteiramente da união com os outros homens. A linguagem conceitual é objeto de intercâmbio cultural e eleva o homem acima dos outros animais. Em conseqüência, o homem alcança seu pleno desenvolvimento humano, físico e espiritual, somente mediante as relações com os outros. O fundamento último da dimensão de intersubjetividade reside no fato de que o ser do homem tem necessidade de um complemento; e a razão desse complemento se encontra na essência mesma do homem: espírito encarnado (forma-matéria)".

${ }^{13}$ CORETH, Emerich. ¿Qué es el hombre? Esquema de una antropologia filosófica. Tradução de Andrés Ortiz-Osés. Barcelona: Herder, 1976, p. 226.
} 
definição de pessoa. A realização do ser humano depende do movimento dinâmico de suas tendências e inclinações na direção de seus fins existenciais. O homem é, assim, um ser histórico, porque é um projeto, submetido a um processo de mudança. Sua vocação de plenitude se desenvolve num determinado contexto históricocultural. Cultura é tudo o que o homem constrói para transformar a natureza. E esta é uma construção que se realiza num tempo histórico. Battista Mondin esclarece que o homem não é só o artífice da cultura, mas também seu produto ${ }^{14}$.

O ser humano é um ser histórico. Está em contínuo processo de mudança. Deve se realizar dinamicamente, atendendo às inclinações e tendências de sua natureza que o impulsionam à perfeição. Em virtude de sua constituição fundamental e em razão de seu inserção no contexto cultural, é o homem protagonista de sua própria história. O homem é um ser que precisa ser construído no tempo. Sua vida, como ensina Johannes Hessen, é uma contínua realização de valores no desenrolar histórico da existência ${ }^{15}$. Por tais razões, uma concepção estática do ser humano, sem referência ao contexto histórico, acima referido, não pode fundamentar o Direito Natural. Diz o teólogo Bernhard Häring que o homem "e história, possui uma história e determina a história, progredindo da infância à maturidade" ${ }^{" 16}$. A auto-realização é a passagem do ser que se é, como dado, ao ser que deve ser, como projeto. A vida é uma tarefa a ser cumprida na história. É a lição de José Roque Junges, da Unisinos, constante de sua obra Bioética, perspetivas e desafios.

Espiritualidade. O homem é um ser-no-mundo, um ser-com-os-outros e um ser-para-o-Absoluto. A sua realização implica estes três níveis. Importa, agora, salientar a característica da transcendência, que se verifica em todas as realizações humanas e que aponta a Deus. Com ensina Emerich Coreth, a quem sempre nos referimos, o ser humano é "transcendência e realiza seu próprio ser superando-se a si mesmo, se atualiza enquanto se transcende". Assim se expressa o citado professor:

\footnotetext{
${ }^{14}$ MONDIN, Battista. Definição filosófica da pessoa humana. Palestra proferida na Universidade do Sagrado Coração. Bauru: Editora da Universidade do Sagrado Coração, 1998, p. 13-15.

${ }^{15}$ Diz Johannes Hessen que "a vida humana se realiza como humana essencialmente na esfera do sentido", acrescentando que o conceito de sentido acompanha o conceito de valor, pois algo tem sentido na medida em que se encontra em relação com os valores e serve para realizá-los". Concluindo salienta que "a realização da essência , a consumação da personalidade ocorrem por meio dos valores" (Tradução nossa). Cf. HESSEN, Johannes. Tratado de filosofia. Tradução de Juan Adolfo Vázquez. Buenos Aires: Sudamericana, 1970, p. 469 e segs.

${ }^{16}$ Ensina Bernhard Häring que a lei natural depende da realidade histórica. "A lei natural significa a norma de comportamento derivada da própria natureza do homem em sua concreta realidade histórica, enquanto ele tem a capacidade de compreender a si mesmo, de descobrir sua vocação e chamamento, o significado de sua personalidade e de seu relacionamento com Deus, com os outros homens e com o universo criado" (HÄRING, Bernhard . Moral personalista. Tradução de Márcio Fabri dos Santos. São Paulo: Paulinas, 1974, p. 214; 220).
} 
no conjunto de nossa auto-realização pessoal humana experimentamos uma aspiração absoluta que entendemos e afirmamos como plenamente lógica, pois de outro modo a existência humana em geral apareceria como radicalmente absurda. Experimentamos algo absoluto na aspiração da verdade que se ergue em nosso conhecimento; também na experiência incondicional do bem que reclama nosso livre atuar e querer, e sentimos como um dever vinculante. Da mesma forma, do ser e valor pessoais de outro homem deriva para nós algo absoluto, que exige um reconhecimento e respeito incondicionais e que incita à ajuda e amor do semelhante. O ser humano só pode se realizar saindo de si mesmo, na resposta de entrega à exigência absoluta a que deve responder ${ }^{17}$.

O ser humano é assim um ser espiritual, um espírito encarnado, capaz de plasmar e realizar valores. É o que ensina Johannes Hessen, acrescentando, ainda, que desta dimensão essencial decorre o princípio da dignidade da pessoa humana ${ }^{18}$. É ainda o que salienta Igor A. Caruso:

o propriamente humano não é o psico-físico, nem tampouco o espiritual; o propriamente humano é a encarnação do espírito e a espiritualização da carne. A solução do problema central da Antropologia deve ser procurada no reconhecimento da íntima e inseparável união do espírito com a matéria, o que vale a aceitar a consciência moral como a nota distintiva do ser humano ${ }^{19}$.

Referida autotranscendência conduz ao fenômeno religioso. $\mathrm{O}$ homem, como salienta Battista Mondin, "além de sapiens, volens, socialis, loquens, ludens é também religiosus" ${ }^{20}$ Em virtude desta última característica, procura superar a si mesmo, procura a auto-realização e o autodesenvolvimento. Esta busca pode ter uma direção teocêntrica quando o ser humano é atraído a Deus. É o ser itinerante em busca do Absoluto, como proclama Gabriel Marcel.

As dimensões que caracterizam a pessoa humana, na forma acima apontada, permitem concluir que a mesma possui categoria espiritual e axiológica não podendo ser, como assinala Nicolas Berdiaeff, parte de um todo cósmico ou social. Possui, em conseqüência, valor absoluto, com capacidade de auto-realização ${ }^{21}$.

\footnotetext{
${ }^{17}$ Tradução nossa. Cf. CORETH, Emerich, Qué es el hombre? Esquema de una antropologia filosófica. Tradução de Andrés Ortiz-Osés. Barcelona, p. 249 e segs.

${ }^{18}$ HESSEN Johannes.Tratado de filosofia. Tradução de Juan Adolfo Vázquez. Buenos Aires: Sudamericana, 1970, p. 489 e segs.

${ }^{19}$ Tradução nossa. Cf. CARUSO, Igor A. Análisis psíquico y síntesis existencial, relaciones entre el análisis psíquico y los valores de la existencia. Tradução de Pedro Meseguer. Barcelona: Herder, 1958 , p. 222.

${ }^{20}$ MONDIN, Battista. O homem, quem é ele? Elementos de antropologia filosófica. Tradução de R. Leal Ferreira e M. A. S. Ferrari. São Paulo: Edições Paulinas, 1977, p. 218-219.

${ }^{21}$ BERDIAEFF, Nicolas. Cinq meditations sur l'existence. Paris: Aubier, 1936, p. 166.
} 


\section{A dignidade da pessoa humana como princípio reclamado pelo estatuto ontológico da pessoa}

Do estatuto ontológico da pessoa humana, isto é, de sua natureza espiritual e moral, decorre o princípio da dignidade o qual, por sua vez, constitui a base dos direitos fundamentais. Realmente, como assinala Helmut Coing,

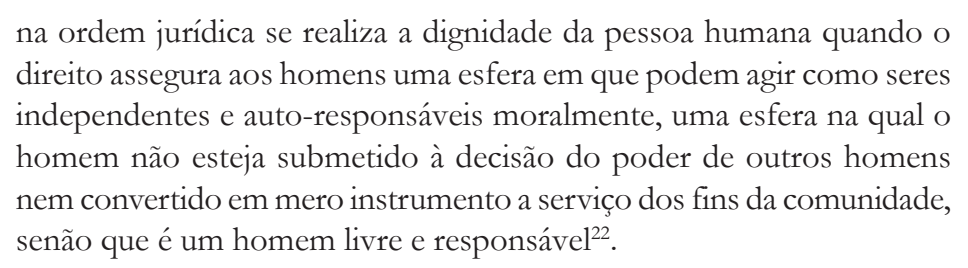
direito assegura aos homens uma esfera em que podem agir como seres independentes e auto-responsáveis moralmente, uma esfera na qual o homem não esteja submetido à decisão do poder de outros homens nem convertido em mero instrumento a serviço dos fins da comunidade, senão que é um homem livre e responsável ${ }^{22}$.

Assim sendo, partindo das dimensões da pessoa (fenomenologia e fins existenciais), vamos estudar a valorização ética (dignidade da pessoa humana como matriz de valores) e concluir com a explicação da gênese dos direitos fundamentais (expressão da dignidade da pessoa humana). De início, entendemos ser necessário revelar, ainda que sumariamente, o significado do princípio da dignidade da pessoa humana bem como o de suas raízes histórico-filosóficas.

O significado do princípio da dignidade da pessoa humana pode ser apreciado sob duplo aspeto: de uma forma positiva, esse princípio evidencia ser a pessoa humana destinada ao cumprimento de fins existenciais, que lhe são próprios, tendo um projeto existencial a realizar; e de uma forma negativa, demonstra que o homem não deve ser simples meio para fins estranhos ou alheios aos seus propósitos, isto é, a pessoa em relação (ser com os outros) não pode ser tida e havida como meio a serviço de outrem.

Do exposto, pode-se concluir que esta formulação, de caráter duplo, traduz a categoria antropológico-ética da dignidade. Karl Larenz assinala que semelhante formulação, além de traduzir um dever ético, é o fundamento ético de toda relação jurídica. É a relação jurídica fundamental. Acrescenta, ainda, o professor da Universidade de Munique que o princípio do respeito é subjacente aos direitos fundamentais e, além disso, tem caráter supra-positivo ${ }^{23}$.

A formulação do princípio, que se encontra na obra Fundamentos da Metafísica dos costumes, de Kant se desdobra em três outros, a saber: a - age como se a máxima de sua ação devesse ser erigida por sua vontade como lei universal; b - age de tal

${ }^{22}$ COING, Helmut. Fundamentos de filosofia del derecho. Tradução de Juan Manuel Mauri. Barcelona: Ariel, 1985, p. 146.

${ }^{23}$ LARENZ, Karl. Derecho justo. Fundamentos de ética juridica. Tradução de Luis Díez-Picazo. Madrid: Civitas, 1985 , p. 55-66. 
maneira que trate a humanidade, tanto na sua pessoa como na de outrem, como um fim e não como um meio; c - age como se a máxima de sua ação devesse servir de lei universal para todos os outros seres racionais.

Realmente, em virtude do valor moral, jamais se pode transformar o homem em meio para fins particulares ou egoístas. O princípio implica no reconhecimento do valor moral da pessoa humana. As pessoas têm dignidade; as coisas têm preço.

Este pensamento de Kant, de inegável repercussão na filosofia moderna e contemporânea, especialmente na do sistema personalista, é fruto de longa evolução histórico-filosófica. A idéia já estava contida na mensagem do cristianismo e em algumas correntes filosóficas que antecederam ao criticismo. Mas, por meio de Kant, veio a se constituir em inspiração para o pensamento moderno e sustentáculo da antropologia personalista contemporânea. Referimo-nos, neste último período, especialmente às contribuições de Maritain, Marcel, Mounier e Berdiaef.

Nesta ordem de considerações, pretendemos apreciar, ainda que numa visão panorâmica, o evolver histórico-filosófico do mencionado princípio. Importa reconstruir a noção para a apreciação do seu sentido no mundo jurídico contemporâneo.

Para a efetiva compreensão do evolver histórico, é necessário retroceder ao Velho Testamento. O texto bíblico, logo de início, no Gênesis, proclama que o ser humano foi criado à imagem e semelhança de Deus. Ensina o livro do Gênesis I, 25-28:

Deus disse: Façamos o homem à nossa imagem e semelhança, e que ele domine os peixes do mar, as aves do céu, os animais domésticos, todas as feras e todos os répteis que rastejam sobre a terra. Deus criou o homem à sua imagem; à imagem de Deus ele os criou, homem e mulher ele os criou.

A Bíblia de Jerusalém explica que o homem é pessoa, com similitude geral de natureza, inteligência, vontade e poder. Além disso, o casal humano passou a ocupar posição especial na hierarquia dos seres, tendo sobre estes o poder de domínio. A doutrina da "imago Dei" é de índole teológica, mas veio a constituir a matriz de toda a colocação filosófica. No Novo Testamento, ressurge o postulado da dignidade, inerente à imago Dei, acompanhado com o corolário da igualdade. Em razão da imagem e semelhança, todos os homens devem ser tratados igualmente como filhos de Deus. Diz o Novo Testamento: "Não há judeu, nem grego, nem escravo nem livre, não há homem nem mulher, pois todos são um só em Jesus Cristo” (Epístola de São Paulo aos Gálatas 3,28). O mesmo pensamento vem consignado em Colossenses 3, 11, Romanos 10,12 e Efésios 4,4-624. Para o Novo Testamento, a

${ }^{24}$ BÍBLIA de Jerusalém. São Paulo: Paulinas, 1985, p. 32, nota de rodapé n. 11; Colossenses 3, 11: “Aí não há mais grego ou judeu, circunciso e incircunciso, bárbaro, escravo, livre, mas Cristo é tudo em 
dignidade está, na sua explicação última, ligada, não só à Criação, mas, também, à Redenção operada por Jesus Cristo.

O princípio da dignidade da pessoa humana, atualmente considerado como princípio normativo dos direitos fundamentais de personalidade, sociais e culturais, tem seu substrato no cristianismo. A formulação moderna do princípio de respeito recíproco constitui a tradução, em linguagem filosófica, de "considerações genuinamente cristãs e das conseqüências que dele derivam para o direito" no expressivo dizer de Karl Larenz ${ }^{25}$. Por sua vez, o teólogo evangélico Emil Brunner corrobora esse entendimento, salientando que a doutrina cristã (refere-se à "imago Dei”) constitui o fundamento da "idéia européia de justiça, baseada em iguais direitos originários de todos os homens" ${ }^{\text {26. }}$.

\section{Evolução histórico-filosófica do princípio da dignidade da pessoa humana desde a filosofia clássica até o momento marcante de sua efetiva configuração}

A compreensão do evolver histórico filosófico desse princípio está na dependência do que, ao longo da História da Filosofia, manifestaram, a respeito do ser humano, os diferentes sistemas filosóficos, a saber, a antiguidade clássica, a

todos": Romanos 10,12: "De sorte que não há distinção entre judeu e grego, pois êle é o Senhor de todos, rico para todos os que o invocam"; Efésios 4, 4-6: "Há um só Corpo e um só Espírito, assim como é uma só a esperança da vocação a que fostes chamados; há um só Senhor, uma só fé, um só batismo; há um só Deus e pai de todos, que é sobre todos, por meio de todos e em todos"; ver, ainda, na nota de rodapé, o seguinte comentário ao texto por último citado: "na nova ordem desaparecem as distinções de raça, religião, cultura e classe social, que dividiam o gênero humano desde a queda. Refazse a unidade em Cristo" (Bíblia de Jerusalém, p. 2215, nota q). Conferir também: BÍBLIA Didactica. Casa de la Bíblia. Tradução de diversos teólogos. Madrid: Sigueme, 1998 (Romanos 10,12, p. 591; Efésios, 4, 4-6 p. 623; Colossenses, 3, 11, p. 630); Conferir, ainda: BÍBLIA Sagrada. Antigo e Novo Testamento. Tradução de João Ferreira de Almeida, Sociedade Bíblica do Brasil; SCHUSTER, Ignacio. Historia sagrada del antiguo y del nuevo testamento. Tradução de Vicente Orti y Escolano da $36^{2}$ ed. da Biblische Geschichte. Barcelona: Herder, 1955.

${ }^{25}$ LARENZ, Karl. Derecho justo. Fundamentos de etica juridica. Tradução de Luis Díez-Picazo. Madrid: Civitas, p. 58.

${ }^{26}$ Assim se expressa Emil Brunner: "O fato de todos os homens serem criados à imagem e semelhança de Deus é o fundamento mais profundo da consciência jurídica da Bíblia. Esta doutrina do Antigo Testamento sobre a dignidade humana não foi modificada no Novo Testamento, pelo contrário foi aprofundada a ponto de tornar-se radical. Mas não é só, pode-se dizer que semelhante doutrina obteve o máximo alcance pela primeira vez, em virtude da fé em Jesus Cristo como Redentor de todos os homens e de todos os povos. Em Jesus Cristo tem a humanidade sua origem comum, assim como seu destino comum. Para quem crê em Jesus Cristo não há nem judeus, nem gregos, nem escravos, nem livres, nem homens, nem mulheres". E conclui: "É nesta doutrina da fé que se funda a idéia européia de justiça, baseada em iguais direitos originários de todos os homens". BRUNNER, Emil. La justicia, doctrina de las leyes fundamentales del orden social. Tradução de Luis Recaséns Siches. México: Centro de Estudios Filosoficos, Universidad Nacional Autónoma de México, 1961, p. 45. 
patrística grega e romana, a escolástica, a filosofia moderna e a contemporânea. No âmbito do presente estudo, é suficiente relembrar as contribuições mais marcantes de cada um desses períodos. Como veremos, princípio da dignidade da pessoa humana é fruto da antigüidade clássica e da incisiva contribuição do cristianismo. No Velho Testamento, com a narrativa da Criação e no Novo Testamento, com a da Redenção realizada por Jesus, o valor intrínseco da pessoa humana, considerada "imago Dei”, adquire contornos definitivos. A Bíblia, na verdade, contém substanciais elementos para a configuração do princípio. Isto posto, pretendemos sublinhar as principais doutrinas que marcaram a construção do imperativo axiológico da ordem jurídica.

$\mathrm{Na}$ filosofia grega, notam-se alguns indícios do princípio, já que no período antropológico e sistemático, chegaram os gregos a afirmar a supremacia da razão, abrindo uma via para o humanismo. A filosofia de Sócrates, constituindo um chamado à interioridade, inaugura o período antropológico, com reflexos no príncípio da dignidade, já que proclamava que todas as coisas portam a marca da Inteligência, tendo o ser humano participação no Divino. Como esclarece Henrique Cláudio de Lima Vaz, a imagem espiritual do homem, preconizada por Sócrates, advém do princípio da interioridade presente em cada ser humano, isto é, da alma. Na visão socrática, tudo gira em torno da valorização ética do ser humano. Além disso, o ser humano, como ensina Emerich Coreth, "encontra-se vinculado à verdade eterna e imutável, sempre vinculante, acima de todas as mudanças deste mundo sensível". É o que se pode aferir do Fédon, de Platão, que se refere à imortalidade da alma e sua semelhança com o ser divino (Fédon 80, a). Desse entendimento decorre o ideal ético endereçado ao conhecimento e prática das virtudes morais. A meta da filosofia socrática passa a ser, nesta ordem de considerações, o ser humano como ser moral. Em virtude da valorização do conhecimento e da virtude, pode-se vislumbrar como subjacente à sua filosofia, a consideração da dignidade humana e do correspondente dever de respeito.

Platão, com a teoria das idéias, sustenta que existem dois mundos: o mundo sensível, em que vivemos, onde tudo é passageiro, onde tudo flui, o mundo das aparências, e o mundo inteligível, eterno, absoluto e causa do mundo sensível. As idéias fazem parte do mundo inteligível, constituindo realidade distinta. Mas nós participamos dessas idéias, que constituem exemplares das coisas do mundo sensível. O conhecimento das idéias eternas é o caminho para a nossa elevação moral. A perfeição do ser humano está no mundo espiritual. Por isso, o homem deve se desligar dos laços materiais, procurando espiritualizar sua vida. Assim, a dignidade da pessoa humana estaria situada na espiritualidade. A descoberta da realidade espiritual foi eclipsada na ciência política, quando o filósofo proclamou a 
superioridade do Estado com relação aos cidadãos. Assevera Alfred Verdross que faltou um passo para a Antropologia de Platão chegar aos direitos fundamentais. $\mathrm{O}$ passo decisivo foi dado, segundo ensinamento do citado professor de Viena, pelo cristianismo, que introduziu nova ética, influenciando a consciência dos povos para as transformações indispensáveis ao nascimento dos direitos humanos. Contudo, como ensina Verdross, Platão foi o primeiro filósofo que reconheceu o princípio da dignidade da pessoa humana ${ }^{27}$.

Por sua vez, Aristóteles, tomando por base a experiência, rejeita a concepção de Platão, relativa ao mundo das idéias. Partindo da natureza humana, sua antropologia reconhece as dimensões relativas ao conhecimento, à liberdade e à sociabilidade. Com efeito, fundamenta a capacidade cognoscitiva no fato de o homem estar habilitado à abstração e de raciocínio. É esta a dimensão que especifica o homem. Proclama, ainda, que o ser humano é portador de liberdade e do poder de decisão. O homem é um ser racional e livre. Além da dimensão volitiva, Aristóteles se refere à sociabilidade. Ensina, ainda, que o homem é um animal social e político por natureza, já que só na comunhão social é capaz de atingir a perfeição do seu ser. Reconhece, em conseqüência, a dimensão social ao lado da dimensão cognoscitiva e da volitiva. Estas três faculdades ou potências da alma seriam suficientes para revelar a essência do homem, mas a dignidade estaria mais no elemento racional. Contudo, sua concepção política chegou a admitir a prevalência dos direitos do Estado por sobre os dos cidadãos, da família e dos demais grupos sociais e a legitimar a escravidão, como instituição natural. A idéia de dignidade, que poderia derivar do constitutivo da pessoa, consoante fórmula acima referida, ficou definitivamente obscurecida pelo pensamento político. O ponto de vista antropológico não se concilia, em todos os termos, com a colocação de ordem política. A admissão da desigualdade social veio abalar o princípio da dignidade da pessoa humana, decorrente da sua concepção de pessoa, cujo dinamismo a impulsiona a uma finalidade perfectível.

Especial referência merece a contribuição da filosofia helenístico-romana, e de um modo marcante a do estoicismo. Trata-se do período do ocaso e dissolução da filosofia grega, que veio a se constituir em sistema pelas figuras de Sócrates, Platão e Aristóteles, acima referidas. Mas, é certo que o estoicismo teve o mérito de contribuir para revigorar o princípio da dignidade da pessoa humana. Nesse sentido, o estoicismo, propugnando por uma ética rigorosa e enaltecendo a conduta moral,

\footnotetext{
${ }^{27}$ VERDROSS, Alfred. La filosofia del derecho del mundo occidental. Visión panorâmica de sus fundamentos e principales problemas. Tradução de Mario de la Cueva. México: Centro de Estudios Filosoficos, Universidad Autónoma de México, 1962, p. 67.
} 
50 apregoa a igualdade e a fraternidade entre os seres humanos, contribuiu para a efetiva compreensão do conteúdo da dignidade.

Após Aristóteles, a filosofia estóica é um marco histórico no desenvolvimento da idéia do direito natural. O pensamento estóico, primeiro na Grécia e depois em Roma, teve inegável importância para a fundamentação da ética e o reconhecimento da dignidade de todos os seres humanos. Vamos destacar apenas as contribuições de Sêneca, representante eloqüente do humanismo estóico, e de Cícero, figura exponencial do pensamento jurídico romano.

Sêneca atribui primazia ao homem e à sua dignidade, destacando a proeminência do espiritual sobre todas as atividades humanas. Os vínculos de solidariedade e auxílio mútuo estão expressos em seus discursos retóricos. Diz que a natureza criou a todos como parentes, estando os homens ligados por vínculos de universal interdependência. E, assim, estabelece, o princípio da igualdade essencial. Existe uma comum filiação divina de todos os homens que não pode ser relegada. A única nobreza é a da alma.

Esse pensamento ético provém da sua antropologia que, partindo da physis estóica, assevera a existência de uma natureza comum. Tal natureza está imbuída de um princípio divino e espiritual. Há, em Sêneca, uma visão panteísta do mundo. Tudo está subordinado ao determinismo cósmico.

Participando todos os homens da natureza comum, a instituição da escravidão, admitida por Aristóteles, não tem sentido algum. Inexistem as diferenças entre o homem livre e o escravo. A escravidão é condenada por princípios de ordem antropológica. Todos os homens são capazes de virtude.

Assim sendo, Sêneca funda todo seu pensamento na idéia de fraternidade e de cosmopolitismo. Em razão da comunidade de natureza, existe entre os homens a fraternidade. Sua doutrina apregoa a dignidade e enaltece os valores humanos. Daí o princípio fundamental: homo res sacra homini ${ }^{28}$. Esse princípio, como assevera Bernhard Häring é o reconhecimento do caráter relacional da natureza humana, o qual encerra a regra da dignidade ${ }^{29}$.

Inexistindo diferenças substanciais entre os homens, sustenta Sêneca que todos participam do mesmo organismo universal. É o bumanum genus. No que se refere a

\footnotetext{
${ }^{28}$ SÊNECA. Epistulae Morales 95,33.

${ }^{29}$ Assim se expressa Bernhard Häring: "A pessoa individual não pode atingir um conhecimento existencial de sua própria liberdade, dignidade e seus direitos básicos, sem se comprometer com a mesma dignidade, liberdade e direitos dos outros" (HÄRING, Bernhard. Livres e fiéis em Cristo, teologia moral para sacerdotes e leigos. Tradução de Isabel Fontes Leal Ferreira. São Paulo: Edições Paulinas, 1978, p. 298). É o que decorre da ética estóica.
} 
esse cosmopolitismo, ensina que todos os homens são cidadãos do mundo, sendo as diferenças de nações puramente circunstanciais. Assim se expressa nas Cartas a Lucílio:

tudo aquilo que vês, que encerra o divino e o humano, é um uno: somos membros de um imenso organismo. A natureza nos criou irmãos, gerando-nos dos mesmos elementos e para os mesmos fins; infundiunos um amor recíproco e nos tornou sociáveis.

Desta configuração antropológica, infere o princípio da dignidade:

comporta-te com os inferiores como gostarias que comportassem contigo aqueles que te são superiores; a natureza me obriga a servir aos homens, sejam estes escravos ou livres, libertos ou livres de nascimento. Ali onde existe um ser humano ali há lugar para benevolência.

Portanto, a dignidade da natureza humana é princípio que promana de seu pensamento, segundo estes princípios: homo res sacra homini; humanum genus. Destes procedem os corolários ou exigências éticas da igualdade social, fraternidade e cosmopolitismo.

Não destoa desse pensamento a contribuição do pensador e jurista Cícero. Depois de proclamar no De Legibus que existe uma lei que não é invenção dos homens, mas "algo eterno que rege o mundo com uma sabedoria que impera e proíbe" ensina que esta mesma lei é "verdadeira, reta razão, conforme a natureza, presente em todos, constante, sempiterna", e acrescenta que "todos os povos, em todos os tempos serão regidos por esta lei eterna e imutável". Do exposto se infere que, em decorrência dessa lei, todos os seres humanos são iguais por sua essencial dignidade. Tais idéias passaram a constituir o substrato da jurisprudência de Roma ${ }^{30}$. Igualmente no De Oficiis, III, 27, se refere à lei natural, ao salientar que todos os seres estão sujeitos à mesma lei da natureza e que uns não devem causar danos aos outros. Logo, tem o ser humano igualdade e unidade, como características que lhes são próprias. Cícero, em seus discursos, apregoa com ênfase os elementos que integram o conteúdo da dignidade. Muito embora não seja esta a terminologia, o certo é que a idéia está contida em toda a sua vasta retórica.

Das colocações iniciais acima expostas, forçoso é concluir que a filosofia grega não chegou, em que pesem as preocupações do estoicismo, a uma afirmação decisiva a respeito da dignidade da pessoa humana. A filosofia da pessoa só apareceu com o cristianismo, com a doutrina da "imago Dei" e da igualdade das pessoas. Segundo

\footnotetext{
${ }^{30}$ Ver, a respeito, as considerações de Biondo Biondi (Arte y ciencia del derecho, estudo sôbre a ciencia do direito como arte do justo. Tradução de Angel Latorre. Barcelona: Ariel, 1953, p. 119 e segs). 
a Carta de São Paulo aos Romanos 2, 11, Deus não faz acepção de pessoas ${ }^{31}$. No pensamento grego, o homem aparece engajado no todo social, ocupando neste determinada posição, não tendo, em conseqüência, valor autônomo. O homem não tem direitos contra o Estado. A filosofia política grega é transpersonalista, de modo que os direitos assegurados aos seres humanos são limitados. Os direitos do Estado prevalecem por sobre os dos indivíduos. Além disso, os direitos são desiguais, já que são concedidos aos cidadãos livres e não aos escravos. A filosofia antiga, com exceção dos estóicos, na forma acima assinalada, não sentiu a injustiça da instituição da escravidão e, assim, não reconheceu o princípio da dignidade da pessoa humana e o direito natural decorrente da natureza da coisa.

$\mathrm{Na}$ verdade, a filosofia grega constituiu alimento sólido à investigação filosófica de todos os períodos subseqüentes. A Filosofia adquiriu, com o pensamento grego, forma autônoma. Mas, o impacto do cristianismo contribuiu para revolucionar toda a escala de valores que os gregos adotavam. As verdades reveladas suscitaram uma global reavaliação do ensinamentos da filosofia antiga. As principais idéias bíblicas que vieram a interpelar o pensamento grego são basicamente cinco: uma nova e radical concepção de transcendência, o criacionismo, o teocentrismo, a providência pessoal, e a revolução dos valores. Referimo-nos, é certo, somente àquelas que merecem ser citadas em razão da matéria do presente trabalho. $\mathrm{O}$ princípio da dignidade da pessoa humana está alicerçado em novas bases. Com o cristianismo, sua formulação adquire extraordinário colorido.

Vejamos, em síntese, a transformação operada pelo cristianismo. De início, uma nova e radical concepção de transcendência provem da mensagem bíblica do monoteísmo. Diz o preceito: "não terás outro Deus além de mim". Disto resulta a proibição da idolatria. A filosofia grega admitia a pluralidade de entidades. Constitui mandamento do Deuteronômio: "quando ergueres os olhos para o céu e vires o sol, a lua, as estrelas, isto é, todo o exército do céu, nem deixes levar nem prostres diante deles e não lhes preste culto". Para o cristianismo, Deus é uno e não se confunde com as coisas. O cristianismo não aceita o politeísmo e nem o panteísmo.

\footnotetext{
${ }^{31}$ Idêntico pensamento no Deuteronômio: "Pois Javé, vosso Deus é o Deus dos deuses, o Senhor dos senhores, o Deus grande, o valente, o terrível, que não faz acepção de pessoas e que não aceita suborno; o que faz justiça ao órfão e à viúva, e ama o estrangeiro, dando-lhe pão e roupa". Lucas, nos Atos dos Apóstolos, 10,34, se refere ao discurso de Pedro, do seguinte teor: "Dou-me conta, em verdade, que Deus não faz acepção de pessoas, mas, que, em qualquer nação, quem o teme e pratica a justiça lhe é agradável". Na verdade, logo após a este discurso, feito na cada do pagão Cornélio, o Espírito Santo "caiu sobre todos os que estavam ouvindo a palavra" (Atos, 10, 44-45), sendo este o "Pentecostes dos gentios" (cf. BÍBLIA de Jerusalém. São Paulo: Paulinas, 2005, p. 252, nota de rodapé). O dom de Deus é concedido a todos, sem predileção de pessoas, como explica Alfred Wikenhauser (Los hechos de los apóstoles. Tradução de Florencio Galindo. Barcelona: Herder, 1981, p. 181).
} 
A segunda idéia é a do criacionismo. As soluções adotadas pelos gregos relativamente à origem dos seres resultava sempre de determinados elementos da natureza. É o que ocorria no período cosmológico da filosofia grega (filosofia da natureza). No período antropológico e sistemático, Platão se refere ao demiurgo, Aristóteles ao Motor Imóvel. Os estóicos aderiam ao panteísmo. Mas a mensagem bíblica explica que Deus é o criador de todas as coisas. Ele criou todas as coisas do nada. Deus disse e as coisas começaram a- existir. Em terceiro lugar, a idéia do teocentrismo. Além de ter criado o mundo, Deus continua sua obra, dirigindo a humanidade e acompanhando sua história. Continua a dirigir o mundo, como também demonstra a Filosofia da História. O pensamento grego era cosmocêntrico. O homem e o cosmos seriam entidades conjugadas: o homem, uma entidade mais elevada, mas sempre uma coisa entre as coisas do cosmos. A mensagem cristã coloca o homem acima de todas as coisas, porque ele é a "imago Dei". A quarta idéia é a da providência pessoal. A providência dos gregos se confunde com o governo do mundo. Não é de ordem pessoal. A mensagem cristã estabelece relacionamento pessoal e íntimo com a Transcendência. Basta relembrar as parábolas do filho pródigo e da ovelha perdida. Finalmente, a revolução dos valores. A mensagem cristã constitui a mais radical revolução dos valores na história da humanidade. É o que revela a formulação programática do Sermão da Montanha (Mateus, 5, 1-11). É o mandamento novo, do amor ao próximo (João, 5, 34-35; Gálatas, 5, 14; Colossenses, 3, 14; Romanos, 13, 8-10).

Do exposto, segue-se que o princípio da dignidade da pessoa humana está inserido em nova sistemática: o homem transcende à "civitas", estando vinculado a Deus. É “imago Dei”. O próprio conceito de pessoa, como salienta Battista Mondin, é estranho à filosofia grega. Com efeito, o conceito de pessoa acentua o singular, o indivíduo, o concreto, enquanto a filosofia grega dá importância só ao universal, ao ideal, ao abstrato. O singular, o indivíduo, o concreto para o pensamento grego tem valor provisório, como momentânea fenomenização da espécie universal, ou então como instante transitório do grande ciclo, que tudo compreende da história"32. Em suma: para o cristianismo, o homem não pode ser absorvido pelo Estado. Dos princípios desta nova colocação, advém o conceito decisivo de pessoa.

A mensagem cristã, explicada pela teologia, que se revelou, nos termos acima expostos, pelo monoteísmo, criacionismo, teocentrismo, providência pessoal e revolução de valores foi submetida, como salienta o mesmo Battista Mondin, a uma análise de fundo racional e filosófico. Com efeito, o pensamento da patrística,

\footnotetext{
${ }^{32}$ MONDIN, Battista. O homem, quem é ele? Elementos de antropologia filosófica. Tradução de R. Leal Ferrreira e M. A. S. Ferrari. São Paulo: Edições Paulinas, 1980, p. 285.
} 
54 partindo da mensagem cristã, procurou estabelecer uma conciliação com a filosofia platônica, do que resultou o primado da pessoa e seus traços essenciais capazes de exprimir sua dignidade.

Estas considerações são suficientes para manifestar o contraste entre o pensamento grego e o pensamento proveniente da mensagem bíblica. Da confluência de ambas as correntes surgiu o pensamento dos padres da Igreja, de inegável importância para estabelecer o conteúdo da dignidade e, em última análise, embasar os direitos naturais.

Não podemos, nos limites do presente estudo, aprofundar a análise da filosofia patrística, mas é imprescindível uma referência a Gregório de Nissa e a S. Agostinho, o primeiro da patrística grega e o segundo da patrística latina. Ambos apresentaram com precisão o conceito de pessoa como "imago Dei", sendo a este inerentes as dimensões antropológicas que evidenciam a dignidade do ser humano.

Segundo ensinamento de Giovanni Reale e Dario Antiseri, o pensamento de Gregório de Nissa abrange três prontos principais: "a prevalência do mundo inteligível sobre o mundo sensível; o conceito de pessoa, não mais fundado sobre a semelhança entre o homem e o cosmo; e a possibilidade de ascender a Deus, removendo tudo de carnal e passional que nos separa dele" ${ }^{\text {"33. }}$

Suas principais obras são "A Grande Catequese" e "A criação do Homem". Ambas constituem síntese dos princípios do cristianismo, mas apresentam estudo, com profundidade, de questões de ordem filosófica. Gregório de Nissa discorda da colocação da filosofia grega, que procurou conceituar o ser humano a partir de elementos do universo. O homem é "imago Dei”.

Seu expressivo ensinamento está contido nos textos que se seguem. Em "A Grande Catequese", Gregório de Nissa ensina:

\begin{abstract}
manifesta-se no homem a mistura do inteligível e do sensível, que é obra da natureza divina, conforme ensina o relato da criação do mundo. Diz, com efeito, que Deus, tomando o barro da terra formou o homem e com o próprio sopro divino, infundiu a vida na sua criatura para que desse modo o elemento terrestre se elevasse juntamente ao divino, e uma só e idêntica graça se expandisse por toda a criação mediante a mistura da natureza inferior com a natureza sobre-humana.
\end{abstract}

\footnotetext{
${ }^{33}$ REALE, Giovanni ; ANTISERI, Dario. História da filosofia. Patrística e escolástica. Tradução de Ivo Storniolo. São Paulo: Paulinas, 2000, v. 2, p. 57. Sobre Gregorio de Nissa, ver importante estudo em Werner Jaeger (Cristianismo primitivo y paiedeia grega. México: Fondo de Cultura Económica, p. 121-140.Título original: Early Christianity and Greek Paideia, Haward University Press).
} 
Completando esta noção, acrescenta, em A Criação do Homem:

Voltemos à criação divina. Façamos o homem à nossa imagem e semelhança. Filósofos pagãos imaginaram coisas mesquinhas e indignas da magnificência do homem, na tentativa de elevar a condição humana; com efeito, disseram que o homem é um microcosmo composto dos mesmos elementos do todo e com este esplendor do nome quiseram fazer o elogio da natureza, esquecendo-se que desse modo tornavam o homem semelhante às características próprias da mosca e do rato, pois também nelas existe a mistura de quatro elementos, porque certamente nos seres animais se vê uma parte mais ou menos grande de cada um dos elementos, sem os quais nenhum ser que participa da sensibilidade teria natureza para subsistir. Que grandeza tem, portanto, o homem, se o consideramos figura e semelhança do cosmo? Deste céu que circunda, da terra que muda, de todas as coisas neles compreendidas e que passam com aquilo que as circunda? Em que consiste, conforme a Igreja, a grandeza do homem? Não na semelhança com o cosmo, mas em ser à imagem do Criador de nossa natureza ${ }^{34}$.

São de Gregório de Nissa ainda os seguintes ensinamentos:

Deus presenteou o homem com todo o gênero de beleza e exornou sua imagem com um espírito apto a conhecer e amar; e, o que é mais, concedeu-lhe uma vontade livre, isto é, um poder de autodeterminação, isento de toda a coação e de toda a sujeição a qualquer poder estranho ${ }^{35}$.

Na primeira parte desse texto, pode-se vislumbrar uma indicação das dimensões do homem, coincidentes com as que já foram evidenciadas no presente trabalho; na segunda, é lícito aferir coincidência com o princípio da dignidade, enunciado por Kant, já esclarecido acima (ítem 3). Do exposto, parece ser correto afirmar que Gregório de Nissa procurou sempre demonstrar que a mensagem cristã e os ensinamentos da filosofia estão em perfeita harmonia ${ }^{36}$. Enfim, podemos concluir com Fernand Van Steenberghen, da Universidade de Louvain, que a teoria do padre capadócio decorre da consideração da dignidade da pessoa humana: de um lado,

\footnotetext{
${ }^{34}$ Conferir os textos em: REALE, Giovanni ; ANTISERI, Dario. História da filosofia. Patrística e escolástica. Tradução de Ivo Storniolo. São Paulo: Paulinas, 2000, v. 2, p. 64-65.

35 Texto da obra "A Criação do homem", 16. A citação se encontra na obra de Philotheus Boehmer e Etienne Gilson (História da filosofia cristã. 2. ed. Tradução de Raimundo Vier. São Paulo: Vozes, 1982, p. 101).

${ }^{36}$ Gregório de Nissa reafirma, em outro texto, de elevada inspiração, a dignidade humana: "Um símbolo dessa tarefa (refere-se ao retorno a Deus) é a parábola bíblica da dracma perdida. A dracma que devemos procurar significa a imagem do Rei em nosso ser; só ele é capaz de dar valor às demais dracmas, isto é, às demais virtudes. Por isso devemos começar por acender a candeia da razão a fim de iluminar o que estava oculto; a seguir, devemos varrer a casa, isto é, depor a impureza da carne por uma conduta irrepreensível. Postas estas condições, depararemos o que procurávamos, e cheia de orgulho a alma convocará suas vizinhas, isto é, as potências cognitiva e volitiva, os afetos da ira e da dor, a fim de participarem de seu regozijo, e admirarem o novo esplendor da imagem de Deus e a beleza indescritível do tesouro encontrado" ( A Criação do homem, 372 D).
} 
56 porque "a alma humana propriamente dita é a alma imortal, sede do pensamento e da liberdade, imagem de Deus, nisto consistindo a verdadeira dignidade do homem; de outro, porque o homem, nesta ordem de considerações, é o fim e o rei da criação" ${ }^{37}$. Embora com outra nomenclatura, o princípio da dignidade da pessoa humana é vivamente ressaltado no pensamento teológico e no filosófico de Gregório de Nissa.

A dignidade da pessoa humana também decorre do pensamento de Santo Agostinho, representante da patrística romana e figura culminante de todo o período dos Padres da Igreja. Étienne Gilson ensina que, segundo S. Agostinho, “toda a criação do universo está organizada segundo o modelo das idéias divinas; toda a ordem e toda a fecundidade provem delas, de forma que o liame fundamental que liga o mundo a Deus é uma relação de semelhança". E acrescenta: "não há nada na natureza que não porte alguma semelhança com a Trindade; todavia a dignidade da imagem não pertence senão ao homem; no homem, a imagem tem um vestígio próprio, que é a referente à sua alma" ${ }^{38}$.

Todos os seres que compõem o universo da criação constituem reflexo de sua obra e revelam sua sabedoria e beleza. Étienne Gilson se refere aos "reflexos trinitários" na criação, salientando, ainda, que "a dignidade da imagem propriamente dita é o apanágio do ser humano, já que é mediante o espírito ou a mente que a alma se abre diretamente a Deus" ${ }^{\prime 39}$.

Vejamos, porém, os textos de Santo Agostinho. Na sua obra De Beata Vita, ele ensina que o corpo e a alma são constitutivos do homem, mas a alma é o princípio vivificante, de modo que o homem é um espírito encarnado; e em La ciudad de Dios assevera que a imagem divina, gravada na alma humana, deixa vestígios na memória, na inteligência de na vontade, transparecendo nessa dimensões humanas. Da mesma forma, no De Trinitate, proclama que há vestígios da imagem de Deus na parte superior da mente ${ }^{40}$.

Em conclusão: a dignidade da pessoa, na visão de S. Agostinho repousa no fato de o homem ser criado à imagem e semelhança de Deus, trazendo em si, vestígios

\footnotetext{
${ }^{37}$ VAN STEENBERGHEN, Fernand. Histoire de la philosophie, période chrétienne. Louvain: Publications Universitaires, 1964, p. 31.

${ }^{38}$ Tradução nossa. Cf. GILSON, Étienne. Introduction a l'Étude de Saint Augustin. Paris: Librairie Philosophique, 1969, p. 275; 288.

${ }^{39}$ BOHEMER, Philotheus; GILSON, Étienne. História da filosofia cristã. Tradução de Raimundo Vier. Petrópolis: Vozes, 1982, p. 184.

${ }^{40}$ Todas as referências são da publicação: SANTO AGOSTINHO. Obras de San Agustin. Madrid: Biblioteca de Autores Cristianos (BAC).
} 
do divino. O ser humano participa da vida divina. Como esclarece Battista Mondin, o homem é portador de dignidade porque é

\begin{abstract}
um valor absoluto e não instrumental (que pertence à ordem do frui e não do uti, segundo a linguagem de S. Agostinho). Mas é claro que o valor absoluto que cabe ao homem é participado. A absoluticidade participada, do valor humano, pressupõe e remete à absoluticidade incondicionada e subsistente do valor Deus. É assim que o homem, enquanto valor absoluto participado reflete e é ícone do valor absoluto e subsistente que é Deus ${ }^{41}$.
\end{abstract}

Pertencendo à ordem do frui e não à ordem do uti, como assinalamos acima, o homem é um ser portador de dignidade. É valor absoluto participado. Para S. Agostinho, a fonte do valor absoluto da pessoa é Deus. Em conseqüência, só a visão teocêntrica possibilita a explicação última do valor da pessoa.

Admitindo, também, o conceito de "imago Dei" é o pensamento da escolástica. Segundo S. Tomás de Aquino, o homem é o apogeu da criação, tendo, em conseqüência, valor absoluto ${ }^{42}$. Tal situação decorre do fato de ser o mesmo dotado de conhecimento, reflexão, liberdade, sociabilidade, enfim, capacidade de decidir a respeito de seu destino e realização existencial. É o centro do cosmos, nele se reunindo todos os graus do ser. É um microcosmos. Em virtude desta colocação antropológica, está inserido numa ordem objetiva e hierárquica de seres, ocupando posição proeminente. Contém, em si, todas as perfeições dos demais seres. É pessoa, isto é, subsistente de uma natureza racional, no conceito de S. Tomás. O homem é, segundo Battista Mondin, "um espírito encarnado, um espírito ligado essencialmente à matéria, e, assim, o nosso espírito sem o corpo não é pessoa, mas o homem só é pessoa graças ao espírito”. É um ser dotado de natureza espiritual, consciente e livre, capaz de auto-realização. Tem consciência do mundo, dos valores e autodeterminação. É pessoa porque subsiste na ordem do espírito. Segundo explica Emerich Coreth, "está inserto numa ordem objetiva e universal que se fundamenta em Deus, o Ser supremo e infinito"43.

Do exposto, segue-se que a filosofia de S. Tomás, na mesma linha do pensamento de S. Agostinho, termina por reconhecer a dignidade da pessoa humana, sob fundamentos antropológicos e teológicos. Sob o ponto de vista puramente antropológico, o homem participa da plenitude da criação, reunindo, em si, todos

${ }^{41}$ MONDIN, Battista. Elementos de antropologia teológica. Tradução de José Maria de Almeida. São Paulo: Paulus, 1990, p. 410.

${ }^{42}$ Suma Teólogica, I, 29,3.

${ }^{43}$ CORETH, Emerich. ¿Qué es el hombre? Esquema de una antropologia filosofica. Tradução de Andrés Ortiz Osés. Barcelona: Herder, 1976, p. 54-55. 
os estratos do ser. Pertence também à ordem espiritual, em virtude de ser a alma o princípio vital do ser. Possui a capacidade de autodeterminação. Tais dimensões evidenciam o fundamento antropológico. Sob o ponto de vista teológico, é imagem e semelhança de Deus, conforme os textos bíblicos acima analisados.

No evolver histórico-filosófico do princípio da dignidade da pessoa humana, merece especial destaque o pensamento do filósofo do Renascimento Pico Della Mirandola. Na época da Renascença, teve início uma nova mentalidade. O pensamento objetivo da Idade Média considerava a pessoa humana no conjunto do ser. A colocação do período humanista-renascentista é diversa: o homem passa a ser colocado no centro do universo, sendo considerado um ser livre e capaz de dirigir seu próprio destino, realizando seu projeto existencial. Trata-se de um período antropocêntrico. Michele Federico Sciacca ressalta que

o humanismo e o renascimento têm em comum os caracteres fundamentais: afirmação do valor e da dignidade da pessoa humana; livre indagação da natureza física sem os limites impostos pela autoridade de Aristóteles e sem a interferência da autoridade religiosa no campo da razão e da experiência ${ }^{44}$.

Pico della Mirandola, cujo pensamento representa uma revivescência do platonismo, demonstra, de forma eloqüente, o princípio da dignidade da pessoa humana, situando o homem no centro do universo e declarando ser ele o artífice de si mesmo. Desta forma, atribui ao ser humano valor incomensurável. No seu famoso Discurso "De Dignitate Hominis", considerado oração elegantíssima, depois de se referir à excelência da natureza humana, caracteriza o homem como "mensageiro da criação, parente dos seres superiores, rei das criaturas inferiores, intérprete da natureza inteira pela agudeza dos sentidos, pela inquirição da mente e luz do intelecto, traço de ligação entre a eternidade imóvel e o tempo transitório". O humanista chamou a atenção para prerrogativa da pessoa: o homem é o centro do universo, "modelador e escultor de sua própria imagem"45. Referindo-se, ao depois, ao Criador, como Supremo Artífice e Pai, relembra a narração bíblica (Gênesis, 2, 1-25), atribuindo, de forma imaginária, ao Supremo Arquiteto, a seguinte mensagem:

A ti, ó Adão, não temos dado nem um sede determinada, nem um aspecto peculiar, nem um munus singular precisamente para que o lugar, a imagem e as tarefas que reclamas para ti, tudo isso tenhas e realizes,

\footnotetext{
${ }^{44}$ SCIACCA, Michele Federico. História da filosofia. Do humanismo a Kant. Tradução de Luís Washington Vita. São Paulo, v. 2, p. 9.

${ }^{45}$ PICO DELLA MIRANDOLA. Discurso sobre a dignidade do homem. Tradução de Luiz Feracini. São Paulo: Edições GRD, 1988, p. 4. Título original: Oratio de Hominis Dignitate.
} 
mas pelo mérito da tua vontade e livre consentimento. As outras criaturas já foram prefixadas em sua constituição pelas leis por nós estatuídas. Tu, porém, não estás coarctado por amarra nenhuma. Antes, pela decisão do arbítrio em cujas mãos de depositei, hás de predeterminar a tua complexão pessoal. Eu te coloquei no centro do mundo, a fim de poderes inspecionar, daí, de todos os lados, da maneira mais cômoda, tudo que existe. Não te fizemos nem celeste, nem terreno, mortal ou imortal, de modo que assim, tu, por ti mesmo, qual modelador e escultor da própria imagem, segundo tua preferência, e, por conseguinte, para tua glória, possas retratar a forma que gostarias de ostentar. Poderás descer ao nível dos seres baixos e embrutecidos; poderás, ao invés, por livre escolha de tua alma, subir aos patamares superiores que são divinos ${ }^{46}$.

$\mathrm{Na}$ impossibilidade de um estudo mais completo relativamente ao evolver histórico do princípio da dignidade da pessoa humana, limitamos nossa análise à consideração dos momentos marcantes do pensamento filosófico desde a filosofia antiga ao período do renascimento. Procuramos, nesta pesquisa, destacar duas figuras exponenciais: Gregório de Nissa e Pico della Mirandola.

Contudo, é inquestionável que a configuração definitiva do princípio da dignidade da pessoa humana é obra de Emanuel Kant. Convém lembrar que a Crítica da razão pura se refere ao problema do conhecimento. O filósofo do criticismo estuda, nessa obra, as faculdades que possibilitam a realização do conhecimento. $\mathrm{Na}$ Crítica da razãa prática, ele desenvolve a teoria moral. Como ensina Ch. Lahr: "A razão especulativa não é toda a razão; ao lado da razão que conhece e cuja função é a de fundar a ciência, existe a razão que comanda e que funda a moral’"47. O pensamento moral e jurídico de Kant, que promana da razão prática se encontra na Crítica da rąão prática e nos Fundamentos da metafísica dos costumes. Nestas obras, ele enfrenta a problemática de ordem moral, que corresponde a uma das quatro questões de seu itinerário filosófico ${ }^{48}$.

No campo da ação, o dever não pode ser simples forma do pensamento. Ele comanda. É superior a nós. Não podemos negar seu valor objetivo. A moralidade é

${ }^{46}$ PICO DELLA MIRANDOLA, op. cit., p. 6. O Discurso sobre a Dignidade do Homem foi objeto de tradução por Maria de Lurdes Sirgado Ganho, sendo publicado, em edição bilingüe, na Coleção de Textos Filosóficos, das Edições 70, Lisboa, 1998.

${ }^{47}$ LAHR, Charles. Cours de philosophie, tome second, morale, métaphysique et histoire de la philosophie. Paris: Gabriel Beauchesne, 1916, p. 541.

${ }_{48}$ As questões fundamentais da Filosofia, segundo Kant, são as seguintes: que posso conhecer? que devo fazer? que me é lícito esperar? e o que é o homem?. Na Introdução à Lógica, onde se encontra indicado o campo da Filosofia, Kant esclarece: “À primeira questão, responde a Metafísica, à segunda a Moral, a terceira a Religião e a quarta a Antropologia. Mas, no fundo poder-se-ia correlacionar tudo à Antropologia, porque as três primeiras questões se referem à última" (conferir o texto constante da obra: La Filosofia en sus textos. De Descartes a Dilthey. Selección, commentarios e introducciones de Julián Marías. Barcelona: Labor,1950, t. II, p.1579). Diz Emerich Coreth que a "questão atinente ao 
60 dada sinteticamente a priori: ela se impõe de modo absoluto, universal e necessário. O fundamento da moral é o dever inerente ao imperativo categórico. Este vale por si mesmo. O imperativo hipotético é meramente condicional, deriva de objeto a que está subordinado; o imperativo categórico exige que a ação seja praticada por si mesma independente de qualquer finalidade. A lei deve ser obedecida pela própria lei. Neste sentido, a ética de Kant é formalista e destoa das concepções hedonistas, utilitaristas, da felicidade (eudemonismo), do estoicismo, enfim dos sistemas que consideram a matéria da atividade moral. A moralidade depende da forma: a ação é correta quando se realiza em obediência ao dever, de maneira independente de sua matéria, seu conteúdo e sua finalidade.

Segundo ensina Roger Verneaux,

o fundamento da moralidade é o dever, sendo este uma lei que provém
a priori da razão e que se impõe por si mesma a todo o ser racional. É
uma espécie de fato no sentido de que não pode ser deduzido de um
princípio superior. Mas é um fato racional e pelo mesmo objetivo.
Traduz-se na consciência pelo imperativo categórico (tradução nossa) ${ }^{49}$.

A ação realizada unicamente em respeito ao dever, sem levar em conta matéria de ordem empírica, é uma ação moral, uma ação valiosa. A fórmula do imperativo categórico é a seguinte: "age sempre segundo uma máxima que possas erigir em lei universal". Desta fórmula fundamental, decorrem três princípios, a saber: primeiro,

obra sempre como se a máxima da tua ação devesse ser erigida em lei universal da natureza; segundo, obra sempre de tal maneira que trates o ser humano em ti e no outro, como um fim e jamais como um meio; e terceiro, obra sempre como se tu foras ao mesmo tempo legislador e súdito na república das vontades livres e racionais ${ }^{50}$.

Nestas condições, Kant reconhece o valor absoluto da pessoa humana, já que tendo o ser humano a dimensão da liberdade e da autonomia deve, nas relações de intersubjetividade, reconhecer a dignidade dos semelhantes e, exigir destes, por idêntico fundamento, o respeito de sua dignidade pessoal. Valor absoluto significa que a pessoa tem dignidade, tem valor que não comporta medida.

\footnotetext{
homem é o fundamento último de toda a Filosofia, ainda que Kant pessoalmente não tenha elaborado uma antropologia nesse sentido. Apesar disso, já deixou em evidência a expressão chave: que é o homem?” (CORETH, Emerich. ¿Qué es el hombre? Esquema de uma antropologia filosófica. Tradução de Andrés Ortiz-Osés. Barcelona: Herder, 1976, p. 59).

49 Tradução para o português do autor. VERNEAUX, Roger. Historia de la filosofía. Curso de filosofia tomista. Tradução de Monteserrat Kirchner. Barcelona: Herder, 1973, p. 189.

${ }^{50}$ Cf. ROGER VERNEAUX, op. cit., p. 189. Esta questão diz respeito à consciência moral. O pensamento acima referido foi baseado no capítulo intitulado Crítica da Raz̃ão Prática da obra: MORENTE, Manuel Garcia. Fundamentos de filosofia, lições preliminares. Tradução de Guilherme de la Cruz Coronado. São Paulo: Mestre Jou, 1980.
} 
É o que esclarece estudo referente à dignidade da pessoa humana, constante do Dicionário de Ética e Filosofia Moral, organizado por Monique Canto Sperber, in verbis.

segundo Kant, cada indivíduo considera necessariamente que sua existência, como agente racional, é um fim em si. Como todos os indivíduos têm as mesmas razões para fazer o mesmo, Kant parece deduzir que, como ser dotado de razão, não se pode impedi-lo de querer que a sua própria existência de agente racional (dotado de autonomia), seja reconhecida por todos como se possuíssem um valor objetivo e não relativo. A partir daí, passamos a admitir que todos os outros agentes racionais (dotados de autonomia) possuem esse mesmo valor objetivo ${ }^{51}$.

A fórmula kantiana teve ampla projeção na filosofia moderna, especialmente na corrente personalista. Efetivamente, para o personalismo moderno, a compreensão do princípio da dignidade da pessoa humana não pode estar desvinculada da dimensão intersubjetiva da pessoa, acima analisada. O princípio deve apreciado em função da compreensão da pessoa humana como ser com os demais. A dignidade da pessoa humana tem dimensão intersubjetiva. É o que ensina Pérez Luño, cuja lição é de suma importância na caracterização dos direitos e deveres fundamentais ${ }^{52}$. Mas, para os fins da presente exposição, é suficiente destacar que o ponto culminante do evolver histórico do princípio da dignidade da pessoa humana é o que resulta da configuração elaborada por Kant.

\section{As exigências éticas que decorrem da imagem valorativa do ser humano. O princípio ético do respeito recíproco como imperativo axiológico nas relações de intersubjetividade}

Das dimensões da pessoa humana acima estudadas decorre sua especial dignidade. Esta passa a ser matriz dos valores que culminam nas exigências éticas, das quais promanam os direitos humanos positivados. Nesta ordem de considerações, pensamos que os valores, provenientes da dignidade da pessoa humana, como

\footnotetext{
${ }^{51}$ CANTO-SPERBER, Monique (org.). Dicionário de ética e filosofia moral. Tradução de Ana Maria Ribeiro Althoff, Magda França Lopes, Maria Vitória Kesser Sá Brito e Paulo Neves. Rio Grande do Sul: Editora da Universidade do Vale do Rio dos Sinos 2003, v. 1, p. 442. Original em francês.

${ }^{52}$ É este o pensamento de Antonio E. Peréz Luño: "Um aspecto importante da noção de dignidade humana proposta por Maihofer é o de partir para a elaboração de seu significado da situação básica (grundsituation) do homem com relação aos demais, isto é, da situação de ser com os outros (mitsein); em lugar de elaborá-la em função do homem singular encerrado em sua esfera individual (selbstsein), que havia servido de ponto de partida de numerosas caracterizações desta idéia. Esta dimensão intersubjetica da dignidade é de suma transcendência para calibrar o sentido e o alcance dos direitos fundamentais que nela encontram seu princípio fundamentador". (Tradução nossa. Cf. PÉREZ LUÑO, Antonio E. Derechos humanos, estado de derecho y constitución. 5. ed. Madrid: Tecnos, 1995, p. 318).
} 
valor fundante, constituem antecedentes lógicos e alicerces axiológicos da positividade dos direitos fundamentais. Os direitos humanos têm fundamento de índole ética. É o pensamento, entre outros, de José de Oliveira Ascenção, ao salientar que "positivisticamente, a dignidade da pessoa humana só pode ser entendida como fórmula vazia aplicável a todos os conteúdos".

Assim é certo que os pressupostos da positivação dos direitos fundamentais, consoante pensamento anteriormente deduzido, são os que se referem às dimensões da pessoa humana, à sua dignidade, e ao valor fundante que desta decorre. A positivação não pode provir de considerações puramente históricas, de circunstâncias decorrentes de determinados momentos históricos. Nas suas razões mais profundas, os direitos humanos a serem positivados emergem do constitutivo ontológico da pessoa humana e do substrato axiológico que esse mesmo constitutivo vem a exigir. Existem princípios axiológicos suprapositivos que formam a base do sistema legal. Assim sendo, a colocação defendida ao longo deste estudo se distancia das doutrinas relativistas, historicistas, positivistas e formalistas. Pensamos que compete ao Direito Positivo a proteção de valores indispensáveis à convivência social, como exigência do jus naturae.

Atendendo a estes pressupostos, entendemos ser devidamente fundamentado o conceito de direitos fundamentais de Fernández-Largo, conceito que leva em consideração, não só as circunstâncias históricas do momento cultural, como também as propriedades essenciais da natureza humana e os valores que desta decorrem. Segundo o professor da Universidade de Salamanca, os direitos humanos constituem um setor da normatividade jurídica referente a valores da pessoa humana em suas dimensões de liberdade, autonomia e igualdade de condições na vida social, que devem ser respeitadas por todas as legislações. Sua formulação é fruto histórico de uma progressiva tomada de consciência das exigências sociais derivadas da excelência da pessoa humana, e que têm sido enunciadas em declarações, leis fundamentais, constituições ou nos ordenamentos como direito fundamental. Estas normas exigem ser reconhecidas em todo ordenamento jurídico como expoente básico da justiça ${ }^{53}$.

A positivação vem para transformar as exigências éticas em direitos fundamentais, acrescendo à característica ética a da juridicidade. Os direitos naturais não perdem a sua essência ética originária, mas, pela positivação, são aperfeiçoados

\footnotetext{
${ }^{53}$ FERNÁNDEZ-LARGO, Antonio Osuna. Teoría de los derechos humanos. Conocer para practicar. Salamanca: San Esteban, 2001, p. 32.
} 
para que tenham validade jurídica. É o que esclarece Javier Hervada ao salientar que a positivação, além de necessária e autorizadora, aperfeiçoa a ordem e integra o sistema com a admissão dos princípios do direito natural ${ }^{54}$.

A presente pesquisa pretende relembrar os substratos axiológicos dos direitos fundamentais. Pensamos que esta é a chave para a compreensão dos direitos humanos positivados. As raízes dos referidos direitos repousam na Axiologia. Em suma: os direitos naturais, que a Ética estabelece, constituem projeção do princípio da dignidade da pessoa humana e paradigma dos direitos humanos positivados. O Direito Natural é a seiva que nutre o Direito Positivo. Não só o Direito legislado, como sua concretização nas decisões judiciais. Como assinala Helmut Coing, "a ordem jurídica deve ser conformada pelos princípios jurídicos naturais". Mas não é só: o professor da Universidade de Frankfurt am Main, acrescenta que "toda sentença adequada é ao mesmo tempo uma porção de direito natural descoberto e positivado" 55 .

Semelhante posicionamento é fruto de uma reflexão de ordem antropológica e axiológica. Como ensina Lorca Navarrete, da Universidade de Malaga, a

fundamentação dos direitos humanos deve ser radical, isto é, deve ir até às suas raízes. E estas se encontram na consideração da dignidade essencial da natureza do homem, de onde nascem como exigências que, ao longo da história, têm propugnado por seu reconhecimento e tutela em normas e leis positivas, demarcando, ao mesmo tempo, os limites da legitimidade de todo o poder público ${ }^{56}$.

Do exposto, segue-se que há uma transposição dos direitos naturais, provenientes da natureza humana e sua dignidade, chamados de direitos humanos, aos direitos fundamentais, positivados. Esta passagem merece algumas ponderações mais

\footnotetext{
${ }^{54}$ HERVADA, Xavier. Introduccion critica al derecho natural. 8. ed. Pamplona: Ediciones Universidad de Navarra, 1994, p. 177.

${ }^{55}$ COING, Helmut. Fundamentos de filosofia del derecho. Tradução de Juan Manuel Mauri. Barcelona: Ariel, 1976, p. 175 e 176. Acresenta o mesmo autor, em obra mais recente que o Direito Natural é "a soma dos princípios enraizados, tanto na ética como na objetividade, para a organização da ordem social. Ele traz portanto a obrigação de organizar a ordem positiva conforme seus princípios”. Acrescenta ainda que "o direito positivo vive do direito natural. Isto em um duplo sentido. Primeiramente, as regras de justiça formam uma das fontes materiais, a partir da qual o direito positivo é criado; mas, por outro lado, o direito positivo é envolvido no desenvolvimento vivo, o qual ele experimenta na aplicação e interpretação, sempre levando em conta o que a justiça exige originalmente". Ensina também que o direito natural é "o ponto de partida para a superação de todos os problemas". Cf. COING, Helmut. Elementos fundamentais de filosofia do direito. Tradução da $5^{a}$ edição alemã por Elisete Antoniuk. Porto Alegre: Sérgio Antonio Fabris Editor, 2002, p. 263 e segs.

${ }^{56}$ LORCA NAVARRETE, José F. Temas de teoría y filosofía del derecho. Madrid: Ediciones Pirámide, 2003, p. 419.
} 
64 decisivas. Pretendemos circunscrever nossa pesquisa a quatro pontos essenciais: análise do ser do homem, com estrutura e dimensões capazes de revelar sua dignidade; coexistência dos seres dotados de igual dignidade; exigências éticas necessárias para assegurar a meta moral do respeito recíproco; correlação entre direitos e deveres fundamentais no âmbito da comunidade.

Análise do ser do homem. Como já esclarecemos anteriormente, o ser humano é portador de determinadas dimensões que o elevam a uma especial posição no mundo da natureza e no mundo da cultura, enfim, na ordem dos seres que compõem a harmonia universal. Segundo Johannes Hessen, filósofo que acolhe o pensamento de S. Agostinho e chega à filosofia dos valores, o homem é possuidor de quatro características, a saber: "consciência do mundo, autoconsciência, consciência dos valores e autodeterminação”. Por isso, diz o professor da Universidade de Colônia, em quem baseamos todo o nosso estudo, o homem é pessoa e "graças à sua personalidade se eleva por sobre todos os estratos do ser que há no cosmos" ${ }^{57}$. Ele é o ápice da criação. Assim sendo, torna-se portador de dignidade, prerrogativa que vem a se constituir em imperativo axiológico da normatividade. Parece ser esta uma base antropológica sólida para a conceituação da dignidade da pessoa humana.

Contudo, como acentua a Antropologia personalista moderna, a dignidade da pessoa humana tem conotação intersubjetiva porque o ser humano está endereçado para a vida comunitária. Desta forma, o dever de respeito, que promana da dignidade, é complementar e recíproco. É imprescindível destacar, dentre as dimensões que evidenciam o estatuto ontológico da pessoa humana, a característica da intersubjetividade. Esta é a fórmula para o equacionamento do problema e a compreensão dos direitos fundamentais.

A Antropologia relacional, acima mencionada, sustenta que o ser-com-os-outros é a característica fundamental da pessoa humana. É esta a dimensão que sustenta o sistema jurídico. Já diziam os romanos ubi societas, ibi jus. Numa síntese esclarecedora preleciona W. Luypen, da Duquesne University:

\footnotetext{
o direito contém em si uma relação de sujeito a sujeito, a intersubjetividade, uma ou outra forma do ser-com-os-outros. Mas estamos no mundo e, por conseguinte, o lugar onde se encontra o direito é a coexistência, o ser do homem como ser junto com outros seres do mundo.
}

\footnotetext{
57 HESSEN, Johannes. Tratado de filosofia. Tradução de Lucia Piossek Presbisch. Buenos Aires: Sudamericana, 1970, p. 919 e segs.
} 
E mais: "a fonte do direito deve ser procurada no homem, mas no homem percebido como existente ou, melhor ainda, como coexistente, com o subjetividade personificada junto a outras subjetividades personificadas no mundo comum" ${ }^{58}$.

A questão, assim colocada, propicia melhor entendimento para o estudo do passo subseqüente, que é o da positivação dos direitos humanos.

\section{A configuração de direitos e deveres humanos realizada pelo processo de positivação como trânsito dos direitos humanos, eticamente definidos, aos direitos fundamentais, juridicamente tipificados}

Toda a argumentação desenvolvida ao longo deste trabalho revela uma linha de pensamento: a de que os direitos humanos constituem arquétipos dos direitos fundamentais. Os direitos naturais constituem parâmetros dos direitos positivos.

Assim sendo, torna-se patente que compete ao Direito Positivo a proteção dos valores indispensáveis à convivência social, que esses direitos representam. Isto é uma exigência decorrente do Direito Natural. Os direitos humanos devem ser objeto de reconhecimento por parte do Direito Positivo, constituindo a positivação o término de um processo lógico, cujos passos ficaram delineados ao longo do presente estudo. Os direitos humanos só podem ser efetivados se forem recolhidos pelo sistema normativo constitucional.

Nesta ordem de considerações, é oportuno recordar que referidos direitos não são objeto de criação, mas de reconhecimento por parte do legislador constitucional. A exigência do reconhecimento é, não só necessária, como desejável, como observa Ezcurdia Lavigne. O mesmo filósofo da Universidade Complutense acrescenta ainda que o Direito Positivo constitui projeção eficaz dos princípios jusnaturalistas ${ }^{59}$. Cabe ao legislador converter os direitos humanos em direitos fundamentais, mediante o processo de positivação. Os direitos humanos, ao serem especificados e protegidos, não perdem a matização ética, mas adquirem, por acréscimo, o caráter de direitos subjetivos. São direitos humanos positivados.

Cabe ao Direito Constitucional não só configurar, como, também, concretizar os direitos humanos. Nesse sentido, a própria Encíclica "Pacem in Terris", de João XXIII, já citada, diz que os direitos humanos devem ser reconhecidos, respeitados,

\footnotetext{
${ }^{58}$ LUYPEN, William A. Fenomenologia existencial. Tradução de Pedro Martín y de la Cámara. Buenos Aires: Ediciones Carlos Lohlê, 1967, p. 228-229.

${ }^{59}$ EZCURDIA Lavigne, José A. Curso de derecho natural. Perspetivas jusnaturalistas de los derechos Humanos. Madrid: Reus, 1987, p. 47-49.
} 
harmonizados, tutelados e promovidos ${ }^{60}$. Esta é a missão do Direito Constitucional. É surpreendente que as expressões consignadas na Encíclica e referentes à tarefa do legislador coincidam com a moderna perspectiva de positivação e concretização dos direitos fundamentais.

A dignidade da pessoa humana, considerada na perspectiva intersubjetiva ou comunitária, está a sinalizar para o princípio do respeito recíproco, consubstanciado em normas éticas, de caráter suprapositivo, as quais, por sua própria natureza, exigem a necessária positivação, mediante a configuração e proteção dos direitos fundamentais. É esta a conclusão necessária que decorre da colocação das premissas que os dados prévios revelam.

\section{Enunciados finais}

As proposições que se seguem resumem as principais posições assumidas e reproduzem as definições analítico-descritivas propostas ao longo de nosso estudo.

1 - As declarações universais de direitos humanos contém princípios normativos aptos a revelar os valores superiores que devem presidir toda ordenação sistemática.

2 - É necessário pesquisar sobre os pressupostos de ordem lógica, ontológica e axiológica que constituem os alicerces dos direitos humanos positivados.

3 - A configuração dos direitos humanos decorre de um processo de descoberta das tendências axiológicas que devem compor a ordem jurídica. Para tanto, releva explicitar os dados prévios que justificam o trânsito dos direitos humanos aos direitos fundamentais, constitucionalmente tipificados. Três premissas são de capital importância, a saber: a que se refere ao ser humano, dotado de dimensões que revelam sua dignidade; a que reafirma que o homem só pode alcançar sua autorealização e autodesenvolvimento no âmbito da vida comunitária; e a que, confrontando as duas anteriores, proclama, como conseqüência lógica, a paridade ontológica dos seres conviventes.

4 - Assim sendo, o princípio da dignidade da pessoa humana é a matriz dos valores que culminam nas exigências éticas que fundamentam os direitos humanos

\footnotetext{
${ }^{60}$ É este o texto da "Pacem in Terris", item 60: "Hoje em dia se crê que o bem comum consiste sobretudo no respeito aos direitos e deveres da pessoa humana. Oriente-se, pois, o empenho dos poderes públicos no sentido de que esses direitos sejam reconhecidos, respeitados, harmonizados, tutelados e promovidos, tornando-se, assim, mais fácil o cumprimendo dos respetivos deveres. A função primordial de qualquer poder público é defender os direitos invioláveis da pessoa humana e tornar mais viável o cumprimento de seus deveres". (Documentos de João XXIII. Tradução da Tipografia Poliglota Vaticana. São Paulo: Paulus, 1998, p. 340).
} 
positivados. Estes emergem do constitutivo ontológico da pessoa humana e de seu substrato axiológico, formando, assim, a base do sistema legal.

5 - Postas estas premissas, surge, como conseqüência lógica, o objetivo da ordem jurídico constitucional: declarar as exigências éticas que decorrem da meta moral de respeito recíproco entre seres portadores de dignidade, bem como a correlação entre os direitos e os deveres fundamentais no âmbito da comunidade. São esses os reflexos que o princípio da dignidade e sua imagem valorativa projetam na esfera jurídica.

6 - A positivação vem para transformar as exigências éticas em direitos fundamentais, acrescentado, àquelas a categoria, da juridicidade. Tais direitos não perdem a essência ética. Reconhecidos pela ordem constitucional, adquirem validez. Passam a ter força normativa. São normas-princípios.

7 - Os direitos humanos constituem guias da conduta convivencial, o que implica, necessariamente, nos correspondentes deveres humanos. Esta correlação decorre da ordem de equilíbrio, e, pois, de justiça, que deve presidir nas relações intersubjetivas.

8 - Este é, segundo entendemos, o processo de justificação dos direitos fundamentais. A configuração dos direitos e deveres fundamentais se realiza pelo processo de positivação, como trânsito, dos direitos humanos, eticamente definidos, aos direitos fundamentais, juridicamente tipificados.

9- O reconhecimento e a tutela dos direitos humanos decorrem de exigências jusnaturalistas. Cabe ao Direito Constitucional converter os direitos humanos em direitos fundamentais. Estes são, em suma, direitos humanos fundamentais.

\section{Referências}

AGOSTINHO, Santo. Obras completas de Santo Agostinho. Madrid: Biblioteca de Autores Cristianos. 20 tomos. De la vida feliz, tomo I; La Ciudad de Dios, tomos XVI e XVII; Tratado da Santissima Trinidad, tomo V. Todos da referida publicação.

ALLPORT, Gordon W. La personalidad. Su configuración y desarrollo. Tradução de Ismael Antichi. Barcelona: Herder, 1993.

ASCENÇÃO, José de Oliveira. Pessoa, direitos fundamentais e direito de personalidade. Revista Mestrado em Direito, Centro Universitário FIEO, ano 6, n.1, 2006.

BERDIAEFF, Nicolas. Cinq meditations sur l'existence. Paris: Aubier, 1936. BÍBLIA de Jerusalém. São Paulo: Paulinas, 2005. 
BÍBLIA do Peregrino. Novo Testamento. Comentários de Luís Alonso Schökel. Tradução de José Bortolini e Ivo Storniolo. São Paulo: Paulus, 2000.

BÍBLIA Didática. Casa de La Biblia. Tradução do texto bíblico por diversos teólogos. Madrid: Sigueme, 1998.

BOHEMER, Philoteus; GILSON, Etienne. História da filosofia cristã. 2. ed. Tradução de Raimundo Vier. São Paulo: Vozes, 1982.

BUCK, Pearl S. La Biblia contada com sencillez. Tradução de J. Valiente Malla. Madrid: Cristianidad, 1973. Título original: The story bible.

BRUNNER, Emil. La justicia. Doctrina de las leyes fundamentales del orden social. Tradução de Luiz Recasens Siches. México: Centro de Estudios Económicos, Universidad Nacional Autónoma de México, 1961.

CANTO-SPERBER, Monique (org.). Dicionário de ética e filosofia moral. Tradução de Ana Maria Ribeiro Althoff, Magda França Lopes, Maria Vitória Kesser Sá Brito e Paulo Neves. Rio Grande do Sul: Editora da Universidade do Vale do Rio dos Sinos 2003, v. 1, p. 442. Original em francês.

CARPINTERO, Francesco. Una introducción a la ciencia jurídica. Madrid: Civitas, 1988.

CARUSO, Igor A. Análisis psiquico y síntesis existencial. Relaciones entre el análisis psiquico y los valores de la existencia. Tradução de Pedro Meseguer. Barcelona: Herder, 1958.

COING, Helmut. Fundamentos de filosofía del derecho. Tradução de Juan Manuel Mauri. Barcelona: Ariel, 1985.

CORETH, Emerich. ¿Qué es el hombre? Esquema de una antropologia filosofica. Tradução de Andrés Ortiz-Osés. Barcelona: Herder, 1976.

EZCURDiA LAVIGNE, José A. Curso de derecho natural. Perspectiva jusnaturalista de los derechos humanos. Madrid: Rialp, 1969.

FERNANDEZ-LARGO, Antonio Osuna. Teoria de los derechos humanos. Conocer y practicar. Salamanca: San Esteban, 2001.

FICHTER, Joseph H. Sociologia. 8. ed. Tradução de Hebe Guimarães Leme. São Paulo: Editora Pedagógica e Universitária da USP, 1967.

GARCIA MORENTE, Manuel. Fundamentos de filosofia. Lições preliminares. Tradução de Guilherme de la Cruz Coronado. São Paulo: Mestre Jou, 1980.

GILSON, Etienne. Introduction a l'étude de Saint Augustin. Paris: Librairie Philosophique, 1969.

HÄRING, Bernhardt. Moral personalista. Tradução de Márcio Fabri dos Santos. São Paulo: Paulinas, 1974.

HESSEN, Johannes. Tratado de filosofia. Tradução Juan Adolphio Vazquez. Buenos Aires: Sudamericana, 1970. 
HERVADA, Xavier. Introducción crítica al derecho natural. 8. ed. Pamplona:

Ed. Universidad de Navarra, 1994.

HOFFNER, Joseph. Doctrina social cristiana. Tradução de Lucio Garcia Ortega. Madrid: Rialp, 1964.

JAEGER, Werner. Cristianismo primitivo y paideia grega. México: Fondo de Cultura Económica.

JOÃO XXIII. Documentos de João XXIII. Tradução da Tipografia Poliglota Vaticana. São Paulo: Paulus, 1996.

JOLIVET, Régis. Traité de philosophie. Introduction Générale, Logique et Cosmologie. Paris: Emmanuel Vitte, 1949. t I.

JUNGES, José Roque. Bioética. Perspectivas e desafios. Rio Grande do Sul: Editora da Universidade do Vale do Rio dos Sinos, 1999.

KAUFMANN, Arthur. Derecho, moral y historidicidad. Tradução de Emilio Eiranova Encinas. Madrid: Marcial Pons, 2000.

LAHR, Charles. Cours de philosophie. Morale, Metaphysique et Histoire de la Philosophie. Paris: Gabriel Beauchesne, 1916. t. II.

LARENZ, Karl. Derecho justo. Fundamentos de ética jurídica. Tradução de Luis Díez-Picaso. Madrid: Civitas, 1985.

LIMA VAZ, Henrique C. Antropologia filosófica. São Paulo: Loyola, 1995. v.1-2.

LORCA NAVARRETE, José F. Temas de teoría y filosofia del derecho. Madrid: Piramide, 2003.

LUCAS LUCAS, Ramon. L'uomo spirito incarnato. Compendio de filosofia dell'uomo. Torino: San Paolo, 1993.

LUYPEN, William A. Fenomenologia existencial. Tradução de Pedro Martíny de la Cámara. Buenos Aires: Carlos Lohlé, 1967.

MARITAIN, Jacques. Elementos de filosofia. A ordem dos conceitos. Lógica menor. Tradução de Ilza das Neves e revisão de Adriano Cury. São Paulo: Agir, 1980. t. II.

O homem e o estado. 4. ed. Tradução de Alceu Amoroso Lima. São Paulo: Agir, 1966.

. Natural law and moral law. In: Challanges and Renewals. Selected Readings edited by Joseph A. Evans and Leo R. Ward. University of Notre Dame, New York Publishing Company, 1968.

MESSNER, Johannes. Ética general y aplicada. Madrid: Rialp, 1969.

MIRANDOLA, Pico della. Discurso sobre a dignidade do homem. Tradução de Maria de Lurdes Sirgado Ganho. Lisboa: Edições 70, 1988. Edição bilingüe. Coleção Textos Filosóficos. 

na Universidade do Sagrado Coração. Bauru: Universidade do Sagrado Coração, 1998.

O homem. Quem é êle? Elementos de Antropologia Filosófica. Tradução de R. Leal Ferreira e M. A. S. Ferrari. São Paulo: Paulinas, 2000.

NUTTIN, Joseph. Psicanálise e personalidade. Tradução de Geraldo Servo. São Paulo: Agir.

PEREZ LUÑO, Antonio E. Derechos humanos, estado de derecho y constitucion. 5. ed. Madrid: Tecnos, 1995.

REALE, Giovanni; ANTISERI, Dario. História da filosofia. Patrística e Escolástica. Tradução de Ivo Storniolo. São Paulo: Paulinas, 2002. v. 2.

RECASENS SICHES, Luis. Tratado general de filosofia del derecho. 11. ed. Mexico: Editorial Porrua, 1995.

ROBLES, Gregorio. Os direitos fundamentais e a ética na sociedade atual. Tradução de Roberto Barbosa Alves. São Paulo: Manole, 2003.

ROMMEN, Heinrich A. O estado no pensamento católico. Tratado de Filosofia Política. Tradução das Monjas Beneditinas da Abadia de S. Maria. São Paulo: Paulinas, 1967.

Derecho natural, historia, doctrina. Tradução de Héctor González Uribe. México: Jus, 1950.

SARLET, Ingo Wolfgang. Dignidade da pessoa humana e os direitos fundamentais na Constituição Federal de 1988. Porto Alegre: Livraria do Advogado, 2006.

SCIACCA, Michele Federico. Historia da filosofia. Do humanismo a Kant. Tradução de Luiz Washington Vita. São Paulo: Mestre Jou. v.2.

SÊNECA. Epistulae morales 95, 33.

SCHUSTER, Ignacio. Historia sagrada del Antiguo y Nuevo Testamento. Tradução de Vicenti Orti. Barcelona: Herder, 1955.

VERDROSS, Alfred. La filosofía del derecho del mundo occidental. Visión panorámica de sus fundamentos e principales problemas. Tradução de Mário de la Cueva. México: Centro de Estudios Filosoficos, Universidad Nacional Autonoma de México, 1962.

VERNEAUX, Roger. Historia de la filosofía. Curso de filosofía tomista. Tradução de Montesserat Kirchner. Barcelona: Heerder, 1973. v. 9.

WIKENHAUSER, Alfred. Los hechos de los apóstoles. Tradução de Florencio Galindo. Barcelona: Herder, 1981. 